\title{
Diversity of the arctic deep-sea benthos
}

\author{
Bluhm A. Bodil • William G. Ambrose Jr • Melanie Bergmann • Lisa M. Clough • \\ Andrey V. Gebruk • Christiane Hasemann • Katrin Iken • Michael Klages • \\ Ian R. MacDonald • Paul E. Renaud • Ingo Schewe • Thomas Soltwedel • \\ Maria Włodarska-Kowalczuk
}

Received: 30 May 2010 /Revised: 16 December 2010 /Accepted: 20 December 2010 /Published online: 11 February 2011

(C) The Author(s) 2011. This article is published with open access at Springerlink.com

\begin{abstract}
A benthic species inventory of 1,125 taxa was compiled from various sources for the central Arctic deeper than $500 \mathrm{~m}$, and bounded to the Atlantic by Fram Strait. The inventory was dominated by arthropods (366 taxa), foraminiferans (197), annelids (194), and nematodes (140). An additional 115 taxa were added from the Greenland-Iceland-Norwegian Seas (GIN). Approximately half of all taxa were recorded from only 1 or 2 locations. A large overlap in taxa with Arctic shelf species supports previous findings that part of the deepsea fauna originates from shelf species. Macrofaunal abundance, meiofaunal abundance and macrofaunal biomass decreased significantly with water depth. Robust diversity indices could only be calculated for the
\end{abstract}

This article belongs to the special issue "Arctic Ocean Diversity Synthesis"

Electronic supplementary material The online version of this article (doi:10.1007/s12526-010-0078-4) contains supplementary material, which is available to authorized users.

B. A. Bodil $(\square) \cdot K$. Iken

School of Fisheries and Ocean Sciences,

University of Alaska Fairbanks,

Fairbanks, Alaska 99709, USA

e-mail: bluhm@ims.uaf.edu

W. G. Ambrose Jr

Department of Biology, Bates College,

Lewiston, Maine 04240, USA

M. Bergmann · C. Hasemann · M. Klages - I. Schewe •

T. Soltwedel

Alfred Wegener Institute for Polar and Marine Research,

27570 Bremerhaven, Germany

L. M. Clough

Department of Biology, East Carolina University,

Greenville, NC 27858, USA polychaetes, for which S, ES(20), H' and Delta+ decreased significantly with water depth, and all but ES (20) decreased slightly with latitude. Species evenness increased with depth and latitude. No mid-depth peak in species richness was observed. Multivariate analysis of the Eurasian, Amerasian and GIN Seas polychaete occurrences revealed a strong Atlantic influence, the absence of modern Pacific fauna, and the lack of a barrier effect by mid-Arctic ridges. Regional differences appear to be moderate on the species level and minor on the family level, although the analysis was confounded by a lack of methodological standardization and inconsistent taxonomic resolution. Future efforts should use more consistent methods to observe temporal trends and

A. V. Gebruk

P.P. Shirshov Institute of Oceanology,

Russian Academy of Sciences,

Moscow, Russia

I. R. MacDonald

Florida State University,

Tallahassee, FL 32306, USA

W. G. Ambrose Jr • P. E. Renaud

Akvaplan-niva AS, Polar Environmental Centre,

9296 Tromsø, Norway

M. Włodarska-Kowalczuk Institute of Oceanology, Polish Academy of Sciences, Sopot, Poland 
help fill the largest sampling gaps (i.e. eastern Canada Basin, depths $>3,000 \mathrm{~m}$, megafauna) to address how climate warming, and the shrinking of the perennial ice cover will alter deep-sea communities.

Keywords Diversity · Arctic · Deep sea - Abundance . Biomass $\cdot$ Polychaeta

\section{Introduction}

The Arctic's central basins have been very poorly studied even compared to other deep-sea areas due to challenging sampling logistics and little obvious need for exploration. In recent decades, however, the central Arctic has received increased attention because of its shrinking sea ice cover (Stroeve et al. 2007) and, very recently, through the International Polar Year 2007-2009. Work from the last two decades has included a number of ecological and faunistic studies that have greatly advanced our knowledge of benthic processes and diversity (e.g., references in Table 1; Klages et al. 2004). In summary, these studies convey a picture of the Arctic deep sea as an oligotrophic area with steep gradients in faunal abundance and biomass from the slopes to the basins primarily driven by food availability, but with overall density and biomass broadly similar to other deep-sea areas. As in other soft sediment habitats, foraminiferans and nematodes generally dominate the meiofauna, whereas annelids, crustaceans and bivalves dominate the macrofauna, and echinoderms dominate the megafauna (see references in Table 1). In total, just over 700 benthic species were catalogued from the central basins a decade ago (Sirenko 2001).

Efforts over the last decade in the Arctic under the umbrella of the Census of Marine Life (Yarincik and O'Dor 2005) have led to descriptions of new species (e.g., Rogacheva 2007; Gagaev 2008, 2009), range extensions (MacDonald et al. 2010), an online Arctic Register of Marine Species (Sirenko et al. 2010), and an open access data base of Arctic diversity data (http://dw.sfos.uaf.edu/ arcod/). Globally, the substantial increase of diversity research in the deep sea in the last two decades was driven by scientific curiosity, but also by the need for baseline inventories in the light of expanding deep-sea fisheries, manganese nodule exploitation, exploratory $\mathrm{CO}_{2}$ deposition, petroleum exploration, tourism, and other human-induced pressures (Thiel 2003). Much of the Arctic deep-sea floor has until now experienced only a weak human footprint (but see Galgani and Lecornu 2004 for Fram Strait), but a predicted ice-free summer in the Arctic in the near future (e.g., Stroeve et al. 2007) may change that situation, thus an up-to-date inventory is urgently needed.
Several paradigms have emerged from deep-sea research in the past decades, including those of mid-depth peaks and latitudinal declines in diversity (Levin et al. 2001; Rex and Etter 2010). Much of the initial work underlying these paradigms was centered in the North Atlantic and the question remains as to whether they apply broadly to the Arctic deep basins that comprise approximately $50 \%$ of the Arctic Ocean seafloor (Jakobsson et al. 2004). The Arctic basins differ from the North Atlantic deep sea because the Arctic deep sea is: (1) largely ice-covered, (2) semi-isolated from the world oceans, (3) relatively young in age (Vinogradova 1997), and (4) experiences more pronounced seasonality in light and primary production than lower latitudes. A peak in benthic diversity at mid-depths $(1,500$ $3,000 \mathrm{~m}$ ) has not been observed for benthic meiofaunal nematode and macrofauna diversity in the central Arctic (Renaud et al. 2006) or for macrofauna in Fram Strait (Włodarska-Kowalczuk et al. 2004). A trend toward reduced taxonomic richness with latitude has been documented for meiofaunal nematode and macrofaunal diversity (Renaud et al. 2006), but not for other community components.

The history and semi-isolation of the Arctic basin play a role in the Arctic basin's diversity patterns (Golikov and Scarlato 1990). Originally an embayment of the North Pacific, the Arctic deep sea was influenced by Pacific fauna until $\sim 80$ million years ago when the deep-water connection closed (Marincovich et al. 1990). Exchange with the deep Atlantic began $\sim 40$ million years ago, coinciding with a strong cooling period (Savin et al. 1975). While some Arctic shelf and deep-sea faunas were eradicated by Pleiostocene glaciations, other shelf fauna in the Atlantic sector of the Arctic found refuge in the deep sea and are considered the ancestral fauna of some of today's Arctic deep-sea fauna (Nesis 1984). The only present-day deep-water connection from the high Arctic to the world oceans through Fram Strait $(\sim 2,500 \mathrm{~m})$ allows exchange with the Greenland and Norwegian Basins (average depth 2,000-3,000 m). Steep ridges form physical barriers within the Arctic basin: the Gakkel Ridge (shallowest depth $\sim 2,500 \mathrm{~m}$ ) separates the Nansen and Amundsen Basins in the Eurasian Arctic (maximum depth $\sim 4,200 \mathrm{~m}$ ), and the Lomonosov Ridge ( $\sim 1,400 \mathrm{~m}$ shallowest depth) separates the Amerasian Canada and Makarov Basins (maximum depth $\sim 3,800 \mathrm{~m}$ ) from the Eurasian Basins (Jakobsson et al. 2004). Despite their boundary character, current evidence suggests the ridges do not form biogeographic barriers (Deubel 2000; Kosobokova et al. 2010). Several other bathymetric features such as the Yermak Plateau north of Svalbard and the Chukchi Borderlands in the Canada Basin contribute to the regional heterogeneity of the Arctic deep sea. 


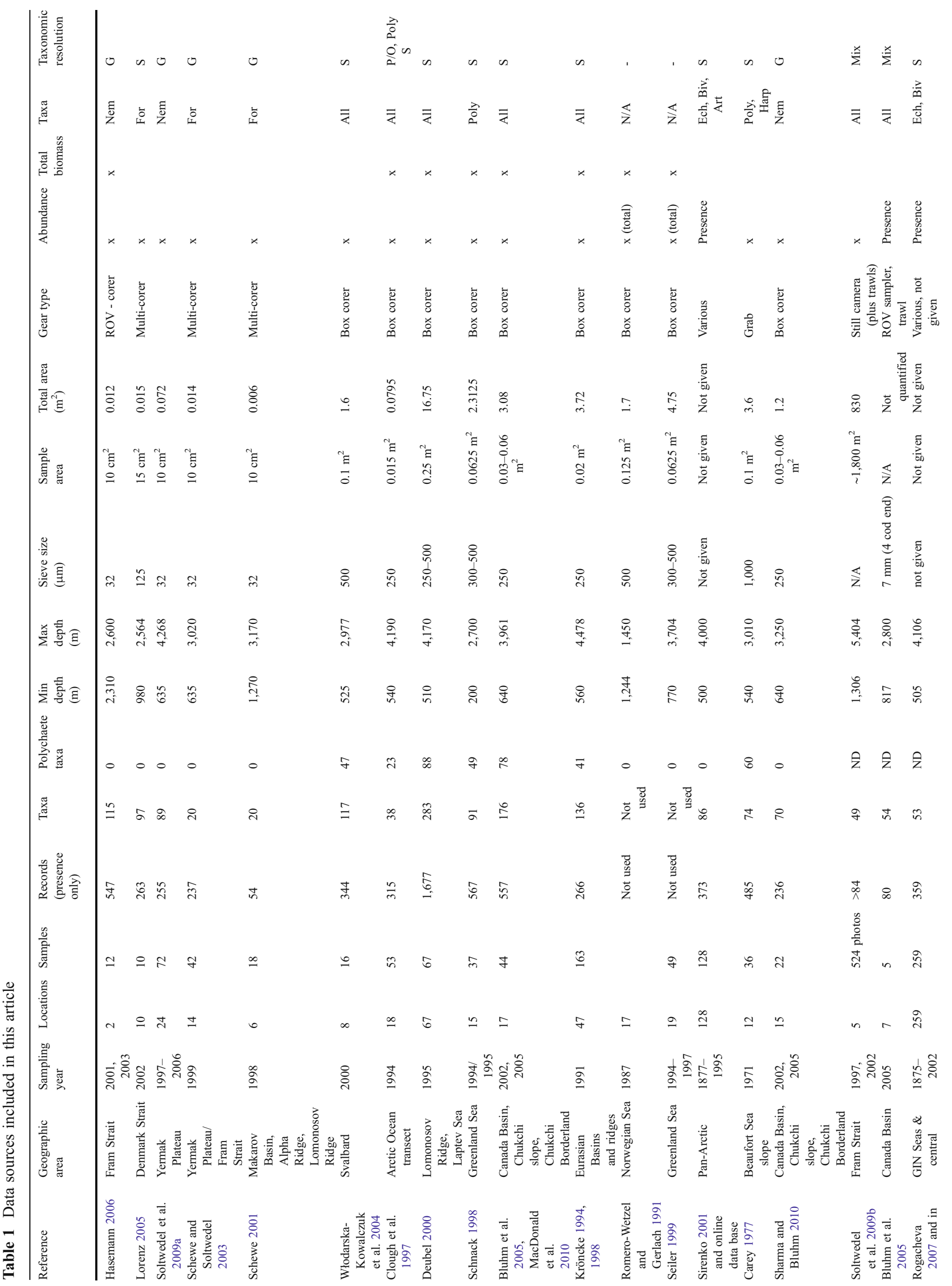


Besides physiography, bathymetry and tectonic history, environmental conditions shape deep-sea diversity including flow regime, sediment characteristics and energy input (reviewed in Levin et al. 2001). The bottom of the Arctic basin is filled with water originating from the North Atlantic (Rudels et al. 1994) that has a very long residence time of $\sim 450$ years in the Canada Basin (MacDonald et al. 1993). In the basins, the sediments are primarily silt and clay while ridges and plateaus have a higher sand fraction (Stein et al. 1994). Exceptions include drop stones, that provide hard substrata and enhanced habitat heterogeneity for benthic fauna (MacDonald et al. 2010; Schulz et al. 2010), and some areas of coarser sediments (Bluhm et al. 2005). Considerable inputs of refractory terrestrial organic matter from the large Russian and North American rivers characterize the organic component of the sediments from the shelves to along the slopes and into the basins (Stein and MacDonald 2004). Overall, the Arctic deep sea receives relatively low input of marine-derived organic matter, because the region is largely covered by multi-year ice, which allows only low average primary production that is highly seasonal (Wheeler et al. 1996; Gosselin et al. 1997). Consequently, carbon flux to the deep-sea floor is low (Olli et al. 2006), but in the slope areas is complemented by carbon advected from some highly productive shelves and from turbidites (Grantz et al. 1996; Cooper et al. 1999; Soltwedel 2000). In the last decade, the perennial ice cover has retreated far over the shelves and into the basins in some areas, in particular over the Chukchi Sea slope and the adjacent southwestern Canada Basin (Stroeve et al. 2007). This may have important implications for spatial patterns in carbon flux and potentially benthic diversity from the slope to deeper basins, patterns that may vary in areas of the Arctic where ice withdrawal has been different.

The goal of our paper is to synthesize information on Arctic benthic deep-sea diversity on a pan-Arctic scale based on numerical analysis of available data from mostly recent faunistic studies of the Arctic deep sea. Our specific objectives in this paper are to:

1 Update the benthic invertebrate taxonomic inventory of the Arctic deep sea (meio-, macro- and megabenthos) relative to the most current comprehensive list (Sirenko 2001)

2 Test for latitudinal and bathymetric trends in diversity, abundance and biomass in the geo-referenced data, and

3 Identify spatial patterns and potential distribution barriers.

\section{Methods}

The data employed are from samples collected during a variety of expeditions largely conducted in the 1990s and 2000 s, but also as early as 1875 , at depths ranging from 
500-5,404 m (Table 1). A total of 5,775 geo-referenced records from 629 locations were compiled for meio-, macroand megafauna with $70 \%$ in the macrofaunal size fraction. Faunal size fractions are defined as meiofauna $>32 \mu \mathrm{m}$, macrofauna $>250-500 \mu \mathrm{m}$, and megafauna typically $>4 \mathrm{~mm}$ and epifaunal. One 'record' is the occurrence of a particular taxon at a specific site with one or more individuals. Sampling gear included primarily multi-corers for meiofauna, primarily box corers for macrofauna, and trawls and camera systems for megafauna (Table 1). Sample areas of the gears used varied, as did the mesh sizes of trawls and the size of sieves used to process sediment samples (Table 1). These differences cause inevitable biases discussed by Gage et al. (2002) that we could partly address (see below), and partly only discuss.

Inventory

To present an updated inventory of the Arctic benthos in water depths $>500 \mathrm{~m}$, we compiled a unique taxon list (Electronic supplemental material, Table 1) for the Arctic deep sea from the data sources in Table 1 (with locations plotted in Fig. 1) and from the column "Arctic basin" in Sirenko (2001). The southernmost boundary on the Atlantic side was in Fram Strait, although additional records from the sub-Arctic
Fig. 1 The study area with symbols marking locations of data records. Some locations include full community data while others represent individual taxon occurrences only. $A m B$ Amundsen Basin, Greenl. Sea Greenland Sea, LR Lomonosov Ridge, MJR Morris Jesup Rise, Norw. Sea Norwegian Sea, NWAP Northwind Abyssal Plain, NWR Northwind Ridge

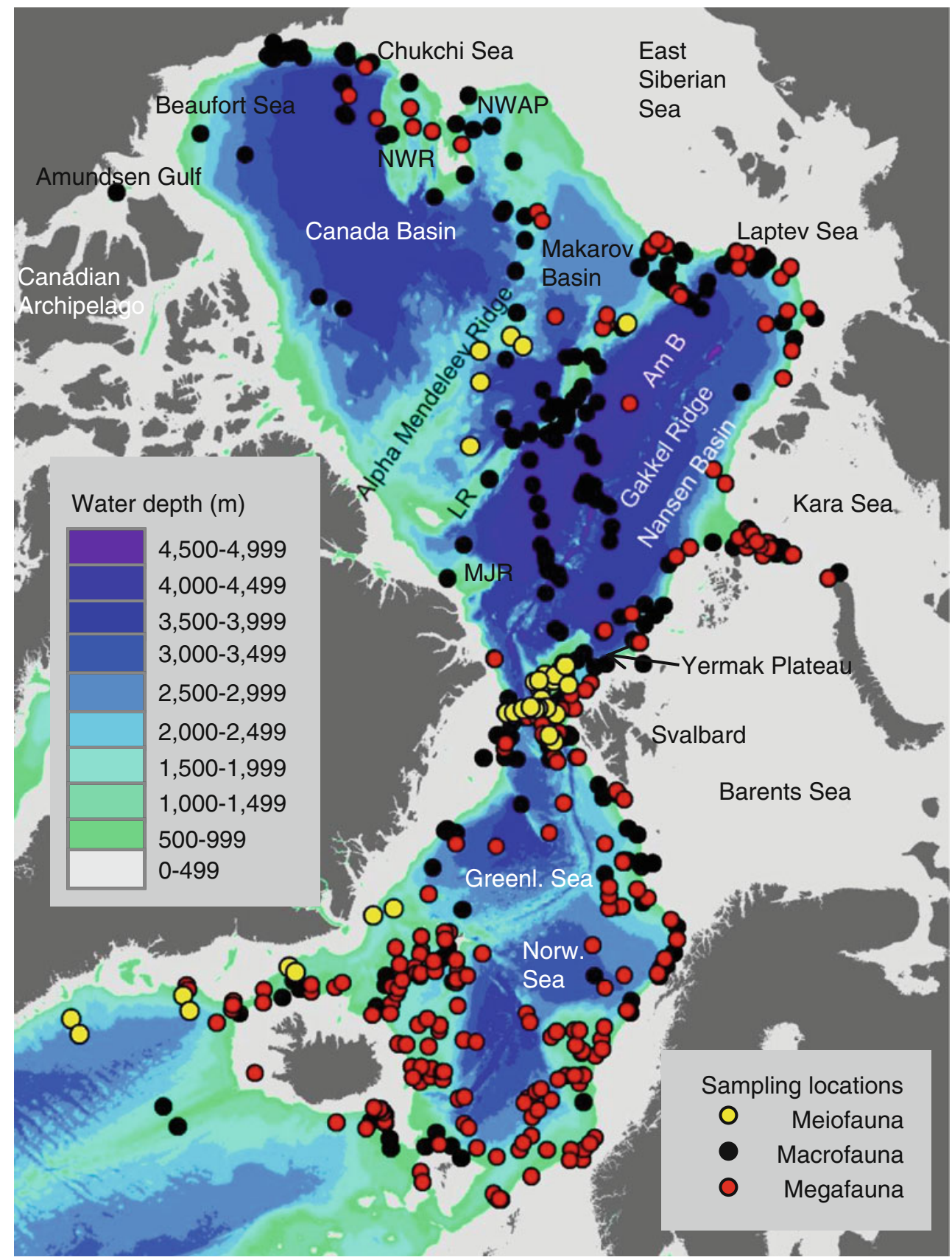


Greenland-Iceland-Norwegian (GIN) Seas were included for comparison (Fig. 1; Electronic supplemental material, Table 1). This list is based on morphological identifications by a wide range of investigators including taxonomic experts and parataxonomists. Taxa identified to genus or family level were only counted towards the unique taxon list when no species-level entry of that genus or family was in the dataset, but were otherwise deleted. Taxa identified by a single investigator as, for example, Chone sp. A-F, were counted towards the total species number only when not represented by other species-level entries for that genus. The list was standardized to the World Register of Marine Species (WoRMS, www.marinespecies.org) using the match function to avoid duplication due to misspellings, synonymies or differences in taxonomic classifications. Taxon names that could not ultimately be reconciled to WoRMS were kept in the dataset if they were found in other recognized species lists such as the Integrated Taxonomic Information System (www.ITIS.gov) or in recent publications. The few remaining taxa $(<1 \%)$ were deleted.

Depth and latitudinal trends and other spatial patterns

Sampling effort per region, sample size, and taxonomic resolution differed among studies (Tables 1 and 2). The highest number of records for any taxon, and the best and reasonably consistent taxonomic resolution, were available for macrofaunal polychaetes from seven datasets with a total of 1,842 taxon records from 238 locations. Therefore, diversity indices were calculated only for polychaetes, with the goal of identifying patterns in Arctic deep-sea benthic diversity. Polychaete data were analyzed using the DIVERSE routine in PRIMER-6 software based on either station means or individual replicates, dependent on data availability. Alpha diversity indices were calculated for stations containing more than two polychaete taxa, thereby excluding 66 of 238 stations and eliminating the depth stratum $>4,000 \mathrm{~m}$ (Table 2). We examined number of taxa (S), Pielou's evenness (J'), ShannonWiener diversity (H'), and average taxonomic distinctness $($ Delta + ). For the calculation of the expected number of taxa found in 20 randomly chosen individuals $\operatorname{ES}(20)$, only samples containing equal to or more than 20 polychaete specimens were included, thereby reducing the number of samples to 127 , excluding most samples with small sampling area $\left(0.015-0.03 \mathrm{~m}^{2}\right)$ and again those samples collected at great depths (Table 2). Delta + is based on presence/absence and describes the average distance between all pairs of species in a community sample, with this distance defined as the path length through a standard Linnean tree connecting these species. Like ES(n), Delta+ is less sensitive to sampling effort than S or H' (Clarke and Warwick 1999, 2001; Magurran
2004). The aggregation file containing the taxonomic hierarchy for calculating Delta+ was created by WoRMS. Differences in diversity indices among groups (4 basins, 15 regions, 4 depth strata, 7 investigators and 4 sample sizes; Table 2) were assessed using one-way analyses of variance with post-hoc Tukey tests (Systat version 13). Taxon accumulation curves $\left(\mathrm{S}_{\mathrm{obs}}\right.$, Chao- 2 ) by sample with 95\% confidence intervals were assembled for different regions and slope, ridge and abyss using EstimateS Software (Colwell 2000).

Depth and latitudinal trends were assessed through Pearson correlations for total abundance (individuals $10 \mathrm{~cm}^{-2}$ for meiofauna, individuals $\mathrm{m}^{-2}$ for macrofauna; insufficient information for megafauna) and total biomass (mg C m${ }^{-2}$; macrofauna only). Where necessary wet-weight was converted to carbon assuming $1 \mathrm{mg} \mathrm{C}=0.034 \mathrm{mg}$ wet weight (Rowe 1983). Spatial patterns in macrofaunal abundance and biomass were produced using ArcGIS version 9.1 (ESRI) with bin sizes determined according to a Jenks' natural breaks classification scheme. This scheme chooses breaksrelatively large jumps in the data values - in the ordered distribution of values that minimize the within-class sum of squared differences. Diversity indices for the polychaete data were regressed on depth and latitude, and the residuals of the depth-latitude and the diversity index-depth relationships were regressed against each other to test for the effect of latitude on diversity independent of depth (Lambshead et al. 2001; Renaud et al. 2006). Differences and similarities in polychaete community structure among major basins, regions, depth strata, investigators, and sample sizes were assessed using non-metric multidimensional scaling (MDS), analysis of similarity (ANOSIM) and similarity of percentages (SIMPER) using PRIMER-6 software.

\section{Results}

Inventory

The compilation of 5,775 geo-referenced records (Table 1) yielded a total of 1,031 different taxa identified to genus or species level. The combination of these records with Sirenko's (2001) non-geo-referenced benthic deep-sea species inventory (712 taxa) yielded a total of 1,240 taxa (including GIN Seas), of which 1,125 taxa occurred only in the central Arctic $\left(>500 \mathrm{~m}\right.$ and north of $80^{\circ} \mathrm{N}$ in Fram Strait; Fig. 2a). Relative to Sirenko's (2001) deep-sea inventory, 413 new taxa were added to the Arctic proper through our effort. The biggest gain in species numbers relative to Sirenko (2001) were in the nematodes, annelids and arthropods (Fig. 2a). The most speciose groups were the arthropods, followed by the foraminiferans, annelids, and nematodes (Fig. 2a). Within the arthropods, amphipods were the most speciose, followed 
Table 2 Factors and number of stations therein used for comparisons of community structure (column $A$ ) and diversity indices (column $B$ except for $\mathrm{ES}(20)$ for which column $C$ applies) of Arctic deep-sea polychaetes

\begin{tabular}{|c|c|c|c|}
\hline & $\begin{array}{l}\text { A. Total number of } \\
\text { polychaete samples }\end{array}$ & $\begin{array}{l}\text { B. Samples with }>2 \\
\text { polychaete taxa }\end{array}$ & $\begin{array}{l}\text { C. Samples with }>20 \\
\text { polychaete invididuals }\end{array}$ \\
\hline \multicolumn{4}{|l|}{ Major Basins } \\
\hline Amerasian Basins & 117 & 85 & 57 \\
\hline Eurasian Basins & 48 & 25 & 24 \\
\hline North Atlantic Basins & 45 & 45 & 33 \\
\hline Lomonosov Ridge & 28 & 17 & 13 \\
\hline \multicolumn{4}{|l|}{ Regions } \\
\hline Amundsen Basin & 24 & 13 & 24 \\
\hline Amundsen Gulf & 1 & 1 & 1 \\
\hline Beaufort Sea slope & 24 & 24 & 23 \\
\hline Canada Basin & 31 & 18 & 31 \\
\hline Chukchi Sea slope & 21 & 16 & 21 \\
\hline Gakkel Ridge & 2 & 0 & 0 \\
\hline Greenland Sea slope & 29 & 29 & 24 \\
\hline Laptev Sea slope & 16 & 16 & 0 \\
\hline Lomonosov Ridge & 28 & 17 & 0 \\
\hline Makarov Basin & 9 & 5 & 0 \\
\hline Mendeleev Ridge & 12 & 4 & 0 \\
\hline Morris Jesup Rise & 4 & 1 & 0 \\
\hline Nansen Basin & 7 & 0 & 0 \\
\hline Northwind Abyssal Plain & 8 & 7 & 0 \\
\hline Northwind Ridge & 4 & 3 & 0 \\
\hline Svalbard slope & 16 & 16 & 0 \\
\hline Yermak Plateau & 2 & 2 & 2 \\
\hline \multicolumn{4}{|l|}{ Depth strata } \\
\hline $500-1000 \mathrm{~m}$ & 58 & 54 & 50 \\
\hline$>1,000-2,000 \mathrm{~m}$ & 72 & 56 & 34 \\
\hline$>2,000-3,000 \mathrm{~m}$ & 62 & 47 & 34 \\
\hline$>3,000-4,000 \mathrm{~m}$ & 37 & 15 & 9 \\
\hline$>4,000 \mathrm{~m}$ & 9 & 0 & 0 \\
\hline \multicolumn{4}{|l|}{ Investigators } \\
\hline Bluhm et al. & 42 & 32 & 12 \\
\hline Carey & 35 & 34 & 33 \\
\hline Clough et al. & 33 & 9 & 0 \\
\hline Deubel & 55 & 47 & 47 \\
\hline Kröncke & 28 & 5 & 2 \\
\hline Schnack & 29 & 29 & 21 \\
\hline Włodarska-K. et al. & 16 & 16 & 12 \\
\hline \multicolumn{4}{|l|}{ Sample size } \\
\hline $0.015-0.03 \mathrm{~m}^{2}$ & 68 & 17 & 2 \\
\hline $0.04-0.0625 \mathrm{~m}^{2}$ & 64 & 58 & 33 \\
\hline $0.01 \mathrm{~m}^{2}$ & 51 & 50 & 45 \\
\hline $0.25 \mathrm{~m}^{2}$ & 55 & 47 & 47 \\
\hline
\end{tabular}

by isopods and harpacticoids (Fig. 2b). Taxa with very few species included bryozoans (1 species), echiurans (1), cephalorynchs (2), ciliophorans (1), and hemichordates (2). By number of records, the five most common species were the polychaete Chaetozone setosa (103 records), the scaphopod Siphonodentalium lobatum (62 records), the polychaete
Myriochele heeri (56 records), the holothuroid Elpidia heckeri (45 records), and the polychaete Aricidea quadrilobata (43 records). Within the arthropods, our most speciose group, the species with the most records were the tanaids Akanthophoreus gracilis (28), Pseudospyrapus anomalus (27), and Pseudotanais affinis (24). 


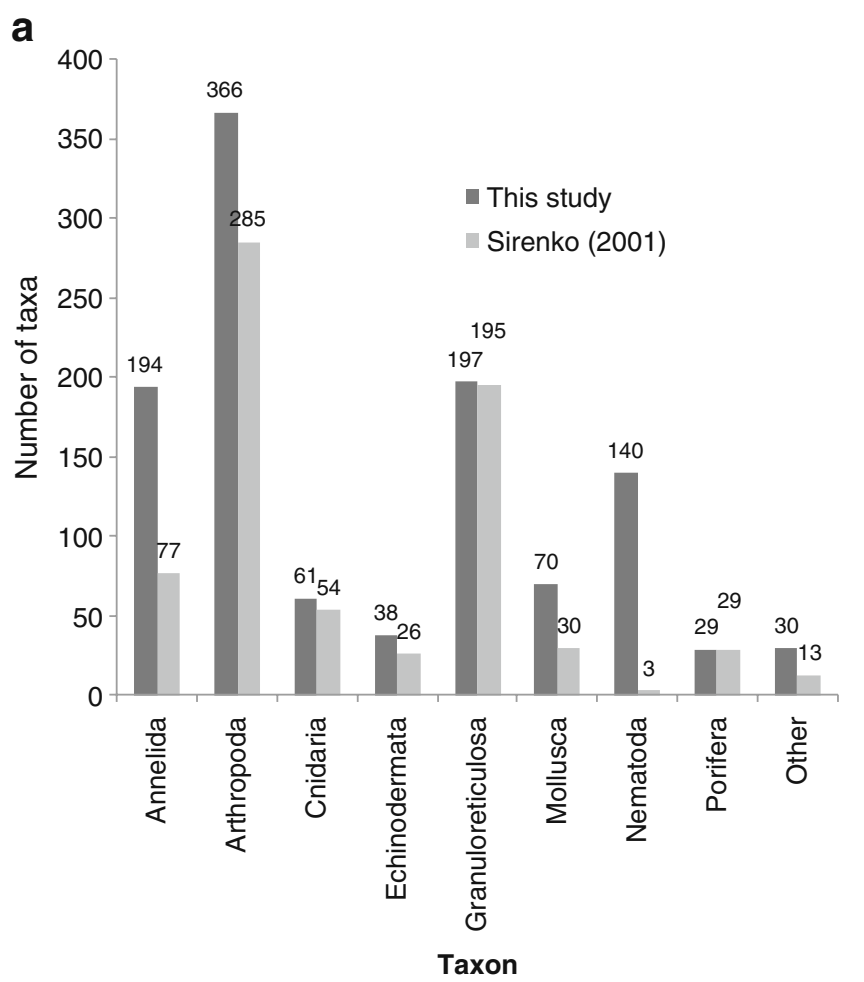

b

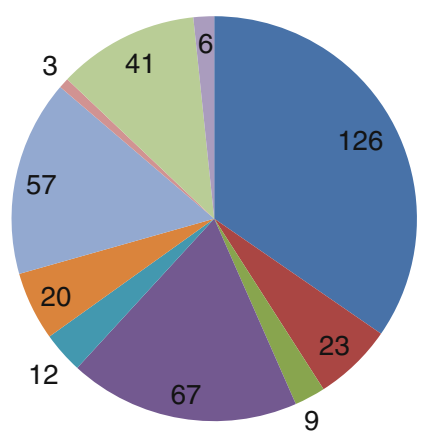

- Amphipoda

- Cumacea

- Decapoda

- Isopoda

Mysida

- Tanaidacea

- Harpacticoida

- Pedunculata

Ostracoda

- Pycnogonida

Fig. 2 Taxonomic composition of Arctic benthic deep-sea fauna a based on geo-referenced taxon records north of $80^{\circ} \mathrm{N}$ on Atlantic side compiled in this paper combined with the most complete previous inventory (Sirenko 2001) (dark bars) and based on Sirenko (2001) only (light bars), b for Arthropoda only (geo-referenced records from this paper combined with Sirenko 2001)

Of the geo-referenced records identified to species and genus level, nearly $50 \%$ were only found at only one or two locations (Fig. 3). In total, 601 of the geo-referenced taxa occurred from $500-<1,000 \mathrm{~m}, 425$ from $1,000-<2,000 \mathrm{~m}$, 267 from $2,000-<3,000 \mathrm{~m}$, and 77 at $\geq 3,000 \mathrm{~m}$, with some taxa occurring in several depth strata. The 254 taxa that only occurred deeper than $1,000 \mathrm{~m}$ in our dataset included recently described species such as the polychaetes Terebellides irinae (Gagev 2009) and Sigambra healyae (Gagaev 2008), and recent first records for the Arctic such as the polychaetes Ymerana pteropoda, and Sosane bathyalis

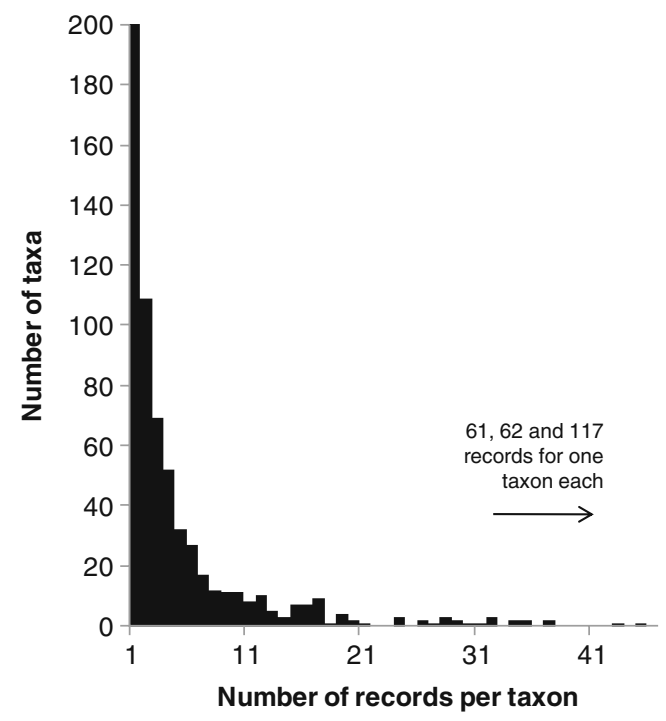

Fig. 3 Distribution of the number of geo-referenced occurrence records per taxon (all taxonomic groups). Close to $50 \%$ of the taxa were only represented by one or two records in the dataset

(Electronic supplemental material, Table 1). The 268 taxa that only occurred shallower than 1,000 m included typical and common shelf species such as the amphipods Ampelisca eschrichti and Byblis gaimardi, the cumacean Diastylis rathkei, the polychaetes Phyllodoce (Anaitides) groenlandica and Maldane sarsi, and the ophiuroid Ophiura sarsii. None of the species accumulation curves reached an asymptote (Fig. 4). The initial slope of the curves was greater for continental slope than for ridge and abyssal samples with no overlap of the $95 \%$ confidence intervals (Fig. 4a). Confidence intervals (not shown) overlapped for most regions in the species accumulation curves by region, where values were lowest for the Amundsen Basin and highest for the Laptev Sea (Fig. 4b). It is noteworthy, however, that abyssal samples typically had fewer individuals than slope samples and sampling area differed widely between studies (Tab. 1).

Latitudinal and depth trends

All observations encompassed large ranges. Total meiofaunal abundance for individual samples ranged from 72 to 4,673 individuals $10 \mathrm{~cm}^{-2}$ (Table 3). Total macrofaunal abundance and biomass for individual samples ranged from 0 to 9,848 individuals $\mathrm{m}^{-2}$ and from 0 to $2,810 \mathrm{mg} \mathrm{C} \mathrm{m}^{-2}$, respectively (Fig. 5). Total megafaunal abundance in individual photographs ranged from 0.1 to 112 individuals $\mathrm{m}^{-2}$ with much greater overall values for HAUSGARTEN stations than Canada Basin stations (Table 3). Meiofaunal abundance, macrofaunal abundance and macrofaunal biomass were significantly and negatively correlated with water depth and latitude, despite considerable variability (Table 4). 
a
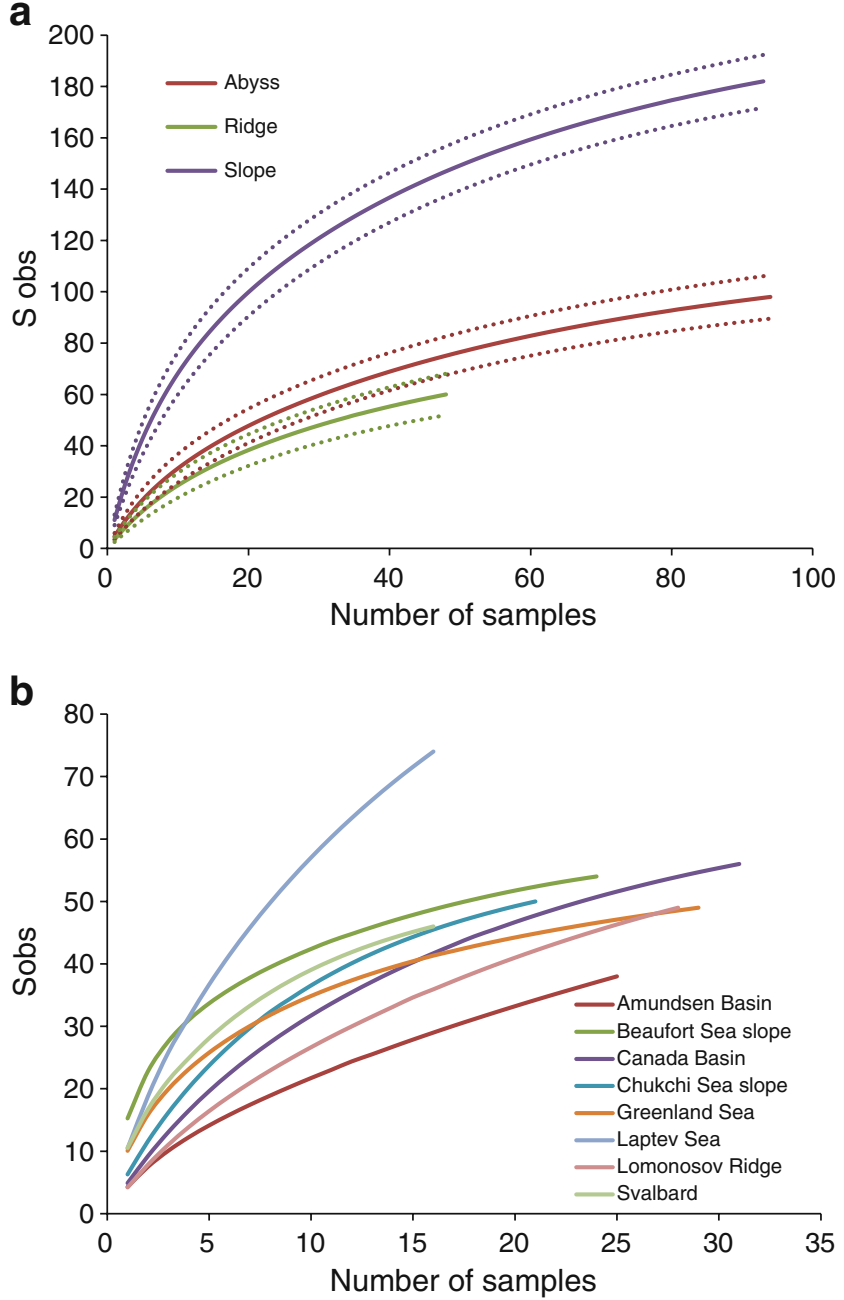

Fig. 4 Species accumulation curves $\left(\mathrm{S}_{\mathrm{obs}}\right)$ for Arctic deep-sea polychaete samples for a slope, ridge and abyssal stations, and $\mathbf{b}$ for those regions that contained 16 or more samples. Means and $95 \%$ confidence intervals (CI) are given for (a), but (CI) were omitted for (b) to enhance clarity

Insufficient meiofaunal biomass, megafaunal abundance and megafaunal biomass data were available to test relationships (but see Soltwedel 2000 for a larger meiofaunal data set).

For the macrofaunal polychaetes, the diversity indices $\mathrm{S}$, H', and Delta+ significantly decreased with depth and latitude, while J' increased significantly (Table 5). Likewise, the regressions of residuals of those indices against depth on the residuals of latitude against depth were significant (i.e., depth and latitude were confounded). ES(20) significantly decreased with depth but not with latitude, and the regression of residuals of $\operatorname{ES}(20)$ against depth on the residuals of latitude against depth was not significant. In all significant cases, only $28 \%$ or less of the variability in the data was explained by depth or latitude, and only $16 \%$ or (much) less was explained by latitude alone (Table 5 ).
Spatial patterns: polychaetes

The community structure of macrofaunal polychaetes differed little among major basins, depth strata or sample sizes, with global $R$ values from $0.10-0.27$, although larger differences were found for some of the pairwise comparisons (ANOSIM; Table 6; Fig. 6a). Specifically, the community structure in samples from $>4,000 \mathrm{~m}$ depth was different from the shallowest samples, and the Greenland Sea, Svalbard and Beaufort Sea slope samples differed greatly from other regions (Table 6). The community structure was significantly different among regions and investigators, with intermediate global $R$ values of 0.41 and 0.46 , respectively (ANOSIM; Fig. 6a, b; Table 6). It must be noted that all investigator teams, except Clough et al., studied only one particular region (Table 1). Dissimilarities of the polychaete fauna among pairs of regions with the highest $R$ statistic (Table 6) were over 95\% (SIMPER). The most similar regions in terms of their polychaete fauna were the Greenland Sea slope and Svalbard (22\%), Svalbard and the Laptev Sea slope (13\%), and Svalbard and the Lomonosov Ridge (13\%). Within-region similarity was highest for the Beaufort Sea slope and Svalbard (both 49\%) and the Greenland Sea slope (41\%). SIMPER analysis showed that the separation by investigator was partly caused by differing taxonomic resolution, for example taxonomic identification as Terebellidae, could have been the same species identified by another investigator as Terebellides $\mathrm{sp}$. or a third investigator as Terebellides stroemi. We, therefore, repeated the analysis on the family level. This reduced the number of taxa for analysis from 224 to 46 . In this case, the separation of polychaete community structure by regions and by investigators was much smaller (Global $R=$ $0.27, p<0.001$ in both cases; Fig. $6 c, d)$ and remained minor by major basins and depth strata (Global $R=0.06$ and $R=0.15$, respectively, $p<0.001$ in both cases).

When stations containing less than 3 polychaete taxa were excluded, $\mathrm{S}$ ranged from 3 to 41 for individual stations, ES(20) ranged from 2.9 to 12.1 , J' ranged from 0.3 to $1, H^{\prime}$ ranged from 0.4 to 3.0 , and Delta + ranged from 77.8 to 100 (means and SD in Fig. 7 and 8). Basinwide patterns showed significant differences for ES(20), J', H', and Delta+ with differences primarily due to higher values in the North Atlantic (except for J') compared to the Amerasian deep sea (Fig. 7). Regional differences were significant for all indices except for Delta+ and were primarily due to high values for the Greenland Sea (ES (20) and H'), higher S or lower J' values for the Beaufort Sea slope, and low values for the Northwind Ridge (ES (20), J', H'). Differences among depth strata were significant for $\mathrm{S}$, J' and $\mathrm{H}^{\prime}$ with highest and lowest values for $500-1,000 \mathrm{~m}$ samples ( $\mathrm{S}$ and J', respectively), and lowest values for deep samples (H'). Differences among investigators were significant for all indices except Delta+, 


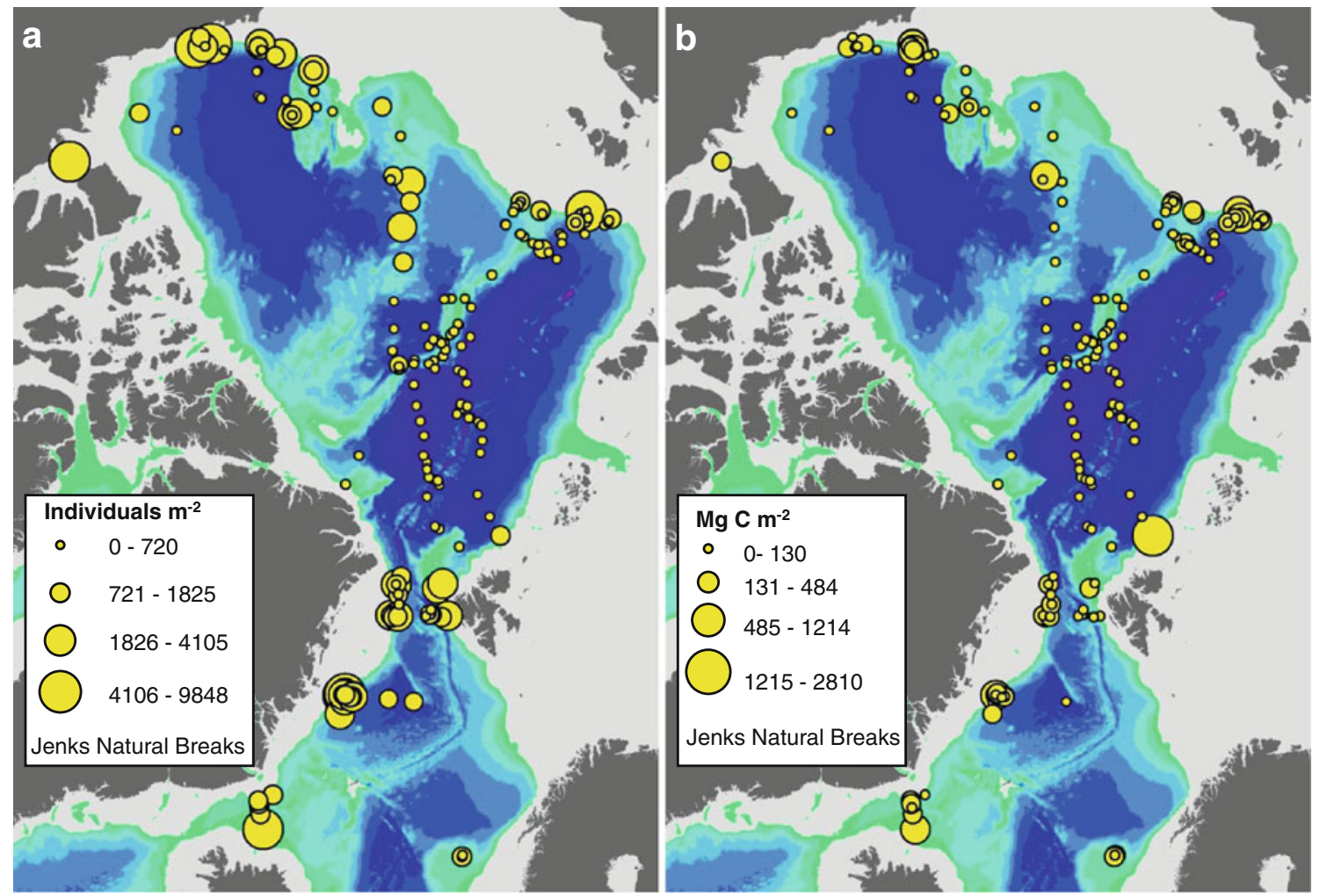

Fig. 5 Distribution of total macrofaunal abundance and biomass in the Arctic deep sea with highest values found generally along the slopes. The legend of the depth contours is in Fig. 1

and were primarily due to particularly high $\mathrm{S}$ and low J' values for Carey, and high values for Schnack (ES(20), H') (Fig. 8). Effects of sample size were significant for S, $\mathrm{ES}(20)$ and J' and were due to highest $\mathrm{S}$ and lowest J' for $0.1 \mathrm{~m}^{2}$ samples and highest $\mathrm{ES}(20)$ values for 0.04 $0.0626 \mathrm{~m}^{2}$ samples. For four of five groupings, Delta + was not significantly different.

\section{Discussion}

Taxonomic patterns

Our taxonomic inventory increased the number of Arctic deep-sea species relative to the most recent list (Sirenko 2001) by more than 400 taxa (and by more than 500 if GIN Seas are included). This increase occurred mostly in the nematodes, annelids and arthropods (Fig. 2). While Sirenko acknowledged that nematodes had poor representation in his list, large gains in annelids and arthropods arise largely because they are the most speciose metazoans in his list, and in most soft-bottom habitats around the world. Nonetheless, we know that our inventory remains incomplete based on the lack of an asymptote in the species-accumulation curves (Fig. 4), the poor sampling coverage in the study area, and the likelihood that datasets not included in our analysis contain additional taxa (e.g., Paul and Menzies 1974; Vanreusel et al. 2000). A reasonable estimate of the actual total number of Arctic benthic deep-sea species can be obtained from the polychaete species-accumulation curves. The Chao-2 estimate for polychaetes from the species-accumulation curve was $282 \pm 19($ mean \pm SD). Polychaetes represented $17 \%$ of all species in our list, so assuming other groups in the inventory are equally incomplete then we would predict a total of $\sim 1,660$ species; $\sim 420$ more than currently in our list. Alternatively, Chao-2 estimated $56(=25 \%)$ more species than $\mathrm{S}_{\mathrm{obs}}$, and adding $25 \%$ to all species gives 310 more species for a total of 1,550. These estimates all assume that we have adequately and representatively sampled the heterogeneity present in the Arctic basin. This is probably not the case: for example, the sampling locations were rather unevenly distributed with particularly large gaps on the eastern side of the Canada Basin, and at depths $>3,000 \mathrm{~m}$ (Fig. 1). Increased sampling in these areas is expected to yield higher total species richness estimates. The number of currently known polychaete taxa may be lower in the Arctic deep sea than in other deep-sea basins of similar size (Table 7), although comparability of the referenced studies is 
Table 3 Abundance and biomass values for Arctic deep-sea meio-, macro- and megafauna

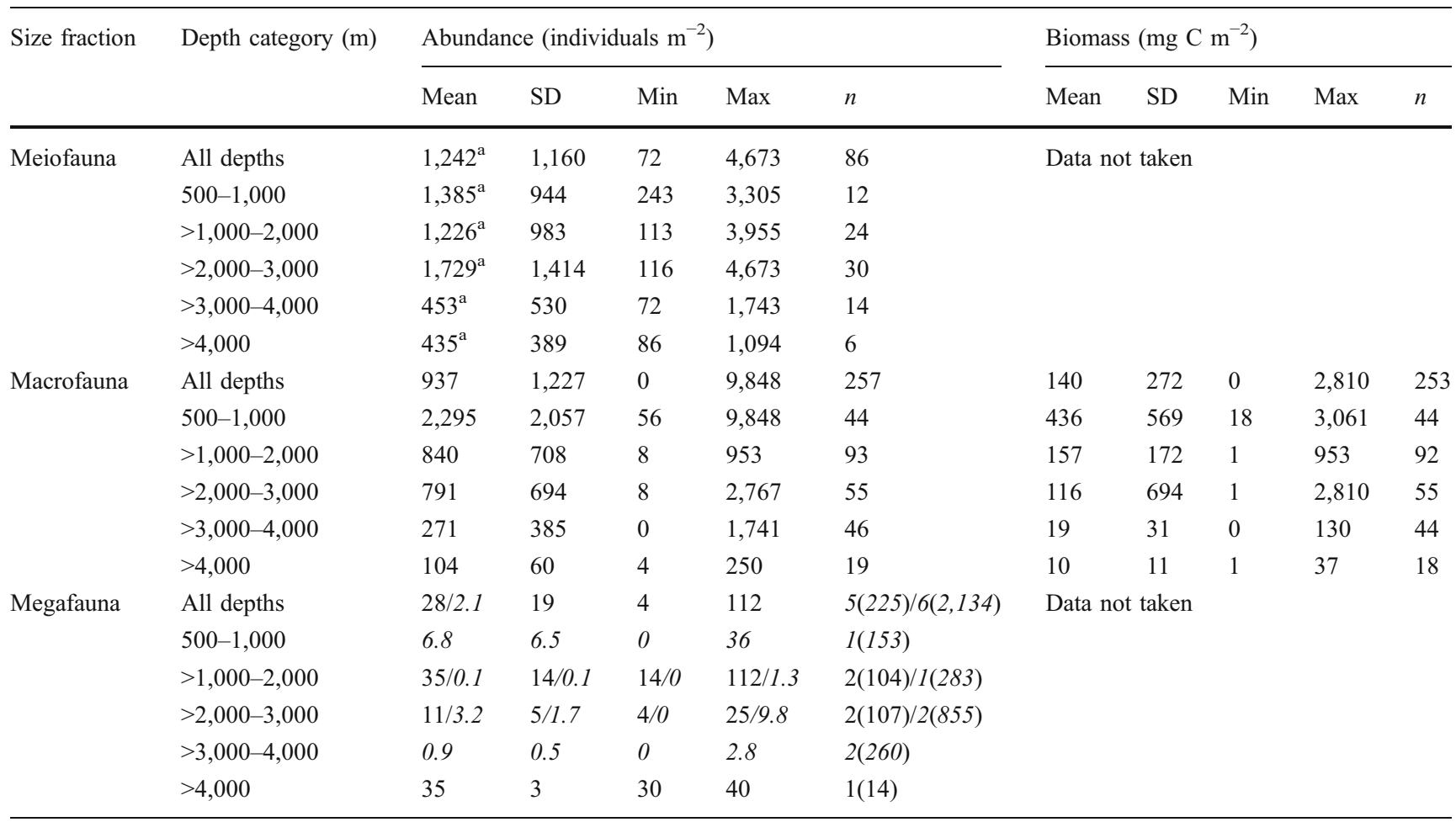

Only two datasets were available for megafauna abundances, which differed greatly between the HAUSGARTEN area and the Canada Basin (in italics), hence their data are presented separately. Sample size $(n)$ for megafauna is given as the number of stations, with the number of photographs per station in parentheses

${ }^{\mathrm{a}}$ Individuals $10 \mathrm{~cm}^{-2}$

complicated by differences in habitat area, depth range, and other methodological differences.

Of the commonly recorded Arctic benthic deep-sea taxa, several are widely distributed, eurybathic species also found on the Arctic and GIN Seas shelves such as the polychaete Myriochele heeri, the tanaid Pseudotanais

Table 4 Pearson correlations of meiofaunal and macrofaunal abundance and macrofaunal biomass versus depth and latitude, respectively

\begin{tabular}{llll}
\hline Correlation & $\begin{array}{l}\text { Pearson's correlation } \\
\text { coefficient }\end{array}$ & $n$ & $p$ \\
\hline $\begin{array}{l}\text { Abundance meiofauna } \times \\
\text { depth }\end{array}$ & -0.213 & 86 & 0.049 \\
$\begin{array}{l}\text { Abundance macrofauna } \times \\
\text { depth }\end{array}$ & -0.428 & 229 & $<0.001$ \\
$\begin{array}{l}\text { Biomass macrofauna } \times \\
\text { depth }\end{array}$ & -0.449 & 247 & $<0.001$ \\
$\begin{array}{l}\text { Abundance meiofauna } \times \\
\text { latitude }\end{array}$ & -0.622 & 86 & $<0.001$ \\
$\begin{array}{l}\text { Abundance macrofauna } \times \\
\text { latitude }\end{array}$ & -0.481 & $229<0.001$ \\
$\begin{array}{l}\text { Biomass macrofauna } \times \\
\text { latitude }\end{array}$ & -0.368 & 247 & $<0.001$ \\
\hline
\end{tabular}

affinis, and the asteroid Pontaster tenuispinus (www.iobis. org). This distribution demonstrates the strong influence of the Arctic shelf fauna (see discussion below) on the deep sea: a comparison of our list with a parallel shelf benthos effort showed that $\sim 60 \%$ of the macro- and megabenthic deep-sea species are shared with the Arctic shelves (Piepenburg et al. 2010). Other common Arctic deep-sea benthic taxa also dominate in other areas of the world's deep sea, for example the well-studied NE Atlantic Rockall Trough (Pain et al. 1982; Tyler et al. 1982; Billett et al. 2001). Examples include elasipodid sea cucumbers, represented in our dataset by the comparatively small species Elpidia heckeri and Kolga hyalina, and the sea stars Bathybiaster vexillifer and Pontaster tenuispinus. The ability of many elasipodids to take advantage of sedimentation events, and their fine trophic niche partitioning (Roberts et al. 2000; Iken et al. 2001), apparently contribute to the success of this group. Isopods and amphipods, taxa that are particularly speciose and widespread in other deepsea areas including the Antarctic (Brandt et al. 2004), were relatively speciose in the Arctic deep sea as well. It is notable that both these groups had a high degree of 
Table 5 Relationships between diversity indices, depth and latitude (Lat.) and of diversity index-depth residuals (Resid.) and latitude-depth residuals

\begin{tabular}{|c|c|c|}
\hline Regression & $R^{2}$ & $p$ value \\
\hline $\mathrm{S} \times$ Latitude & 0.219 & $<0.001$ \\
\hline $\mathrm{S} \times$ Depth & 0.279 & $<0.001$ \\
\hline Resid. S-depth $\times$ resid. Lat.-depth & 0.149 & $<0.001$ \\
\hline $\mathrm{ES}_{(20)} \times$ Latitude & $\underline{0.003}$ & $\underline{0.519}$ \\
\hline $\mathrm{ES}_{(20)} \times$ Depth & 0.133 & $<0.001$ \\
\hline Resid. $\mathrm{ES}_{(20)}$-depth $\times$ resid. Lat.-depth & $\underline{0.011}$ & $\underline{0.127}$ \\
\hline $\mathrm{H}^{\prime} \log _{\mathrm{e}} \times$ Latitude & 0.195 & $<0.001$ \\
\hline $\mathrm{H}^{\prime} \log _{\mathrm{e}} \times$ Depth & 0.253 & $<0.001$ \\
\hline Resid. $H^{\prime} \log _{\mathrm{e}}-$ depth $\times$ resid. Lat.-depth & 0.126 & $<0.001$ \\
\hline $\mathrm{J}^{\prime} \times$ Latitude & 0.179 & $<0.001$ \\
\hline$J^{\prime} \times$ Depth & 0.025 & 0.015 \\
\hline Resid. J'-depth $\times$ resid. Lat.-depth & 0.164 & $\mathrm{p}<0.001$ \\
\hline Delta $+\times$ Latitude & 0.192 & $<0.001$ \\
\hline Delta $+\times$ Depth & 0.171 & $<0.001$ \\
\hline Resid. Delta $+\times$ resid. Lat. - depth & 0.131 & $<0.001$ \\
\hline
\end{tabular}

Non-significant regressions are underlined

rareness, with only one species of each found at more than 10 locations. The lack of epibenthic sled samples in our dataset is perhaps an underlying cause of the patchy and incomplete crustacean spatial patterns, since this gear efficiently samples the epi- and suprabenthic amphipods and isopods (Brandt et al. 2004).

Several phyla previously found to be species poor in the Arctic deep sea continue to be classified as such based our

Table 6 Analysis of similarity (ANOSIM) for the entire polychaete community based on presence/absence data

\begin{tabular}{lll}
\hline Group & $R$ Statistic & Significance level \\
\hline Major basins & $\mathbf{0 . 1 0}$ & $<\mathbf{0 0 1}$ \\
Lomonosov Ridge, North Atlantic & 0.81 & $<0.001$ \\
Regions & $\mathbf{0 . 4 1}$ & $<\mathbf{0 . 0 0 1}$ \\
Lomonosov Ridge, Beaufort Sea & 0.96 & $<0.001$ \\
Lomonosov Ridge, Svalbard & 0.88 & $<0.001$ \\
Lomonosov Ridge, Greenland Sea & 0.96 & $<0.001$ \\
Beaufort Sea, Svalbard & 0.98 & $<0.001$ \\
Beaufort Sea, Greenland Sea & 0.98 & $<0.001$ \\
Beaufort Sea, Chukchi slope & 0.70 & $<0.001$ \\
Beaufort Sea, Laptev Sea & 0.95 & $<0.001$ \\
Greenland Sea, Laptev Sea & 0.86 & $<0.001$ \\
Depth strata & $\mathbf{0 . 1 1}$ & $<\mathbf{0 . 0 0 1}$ \\
$>4,000$ m, 500-1,000 m & 0.56 & $<0.001$ \\
Investigator & $\mathbf{0 . 4 6}$ & $<\mathbf{0 . 0 0 1}$ \\
Carey, Włodarska-Kowalczuk & 0.88 & $<0.001$ \\
Carey, Schnack & 0.93 & $<0.001$ \\
Sample size & $\mathbf{0 . 2 7}$ & $<\mathbf{0 . 0 0 1}$ \\
\end{tabular}

Significant results for Global $R$ (in bold) and pairwise comparisons (only where $R>0.7, p<0.05$ and for regions containing $>15$ samples) 
Fig. 6 Multidimensional Scaling plots of Arctic deep-sea polychaete communities by species $(\mathbf{a}, \mathbf{b})$ and families $(\mathbf{c}, \mathbf{d})$ and color-coded by region $(\mathbf{a}, \mathbf{c})$ and investigator $(\mathbf{b}, \mathbf{d})$
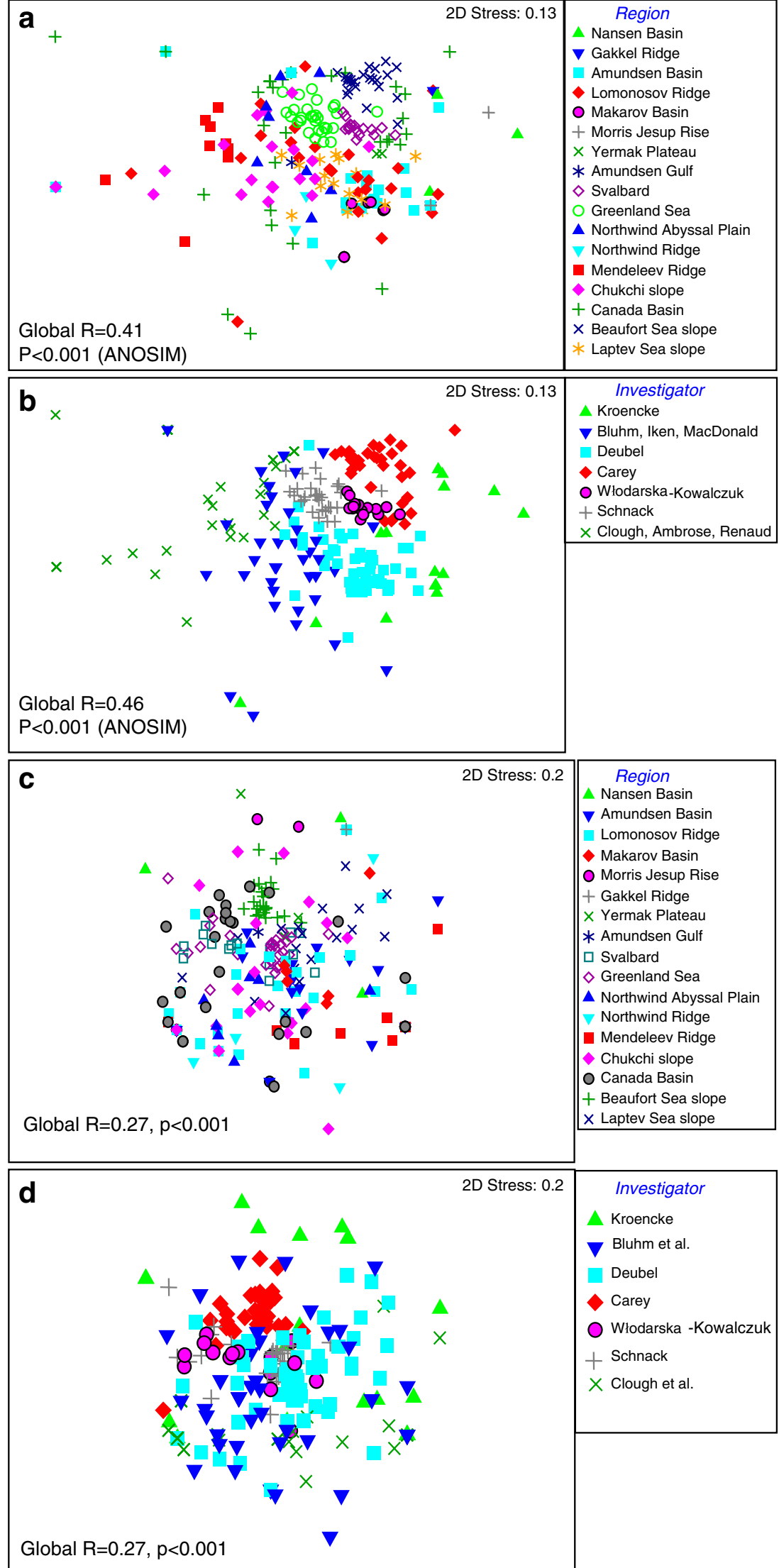
Fig. 7 Means $( \pm$ SE) of diversity indices S, ES(20), J', H', and

Delta+ by major basins, regions, and depth strata for Arctic deepsea polychaete communities. Significant differences are indicated by letters. ES(20) was calculated only for samples that contained 20 or more polychaete individuals which reduced the number of regions relative to the other diversity indices. $A$

Amundsen Basin, Am Amerasian Arctic, Atl North Atlantic, $B$ Beaufort Sea, $C$ Canada Basin, Ch Chukchi Sea slope, Eur Eurasian Arctic, $G$ Amundsen Gulf, $G r$ Greenland Sea, $J$ Morris Jesup Rise, $L$ Laptev Sea slope, $L r$ Lomonosov Ridge, $M$ Makarov Basin, Me Mendeleev Ridge, $N$ Northwind Abyssal Plain, $N R$ Northwind Ridge, $S v$ Svalbard slope, YP Yermak Plateau. Depth strata: 500500 $1,000 \mathrm{~m}, 1000>1,000-2,000 \mathrm{~m}$, $2000 \pm 2,000-3,000 \mathrm{~m}, 3000$ $\pm 3,000 \mathrm{~m}$
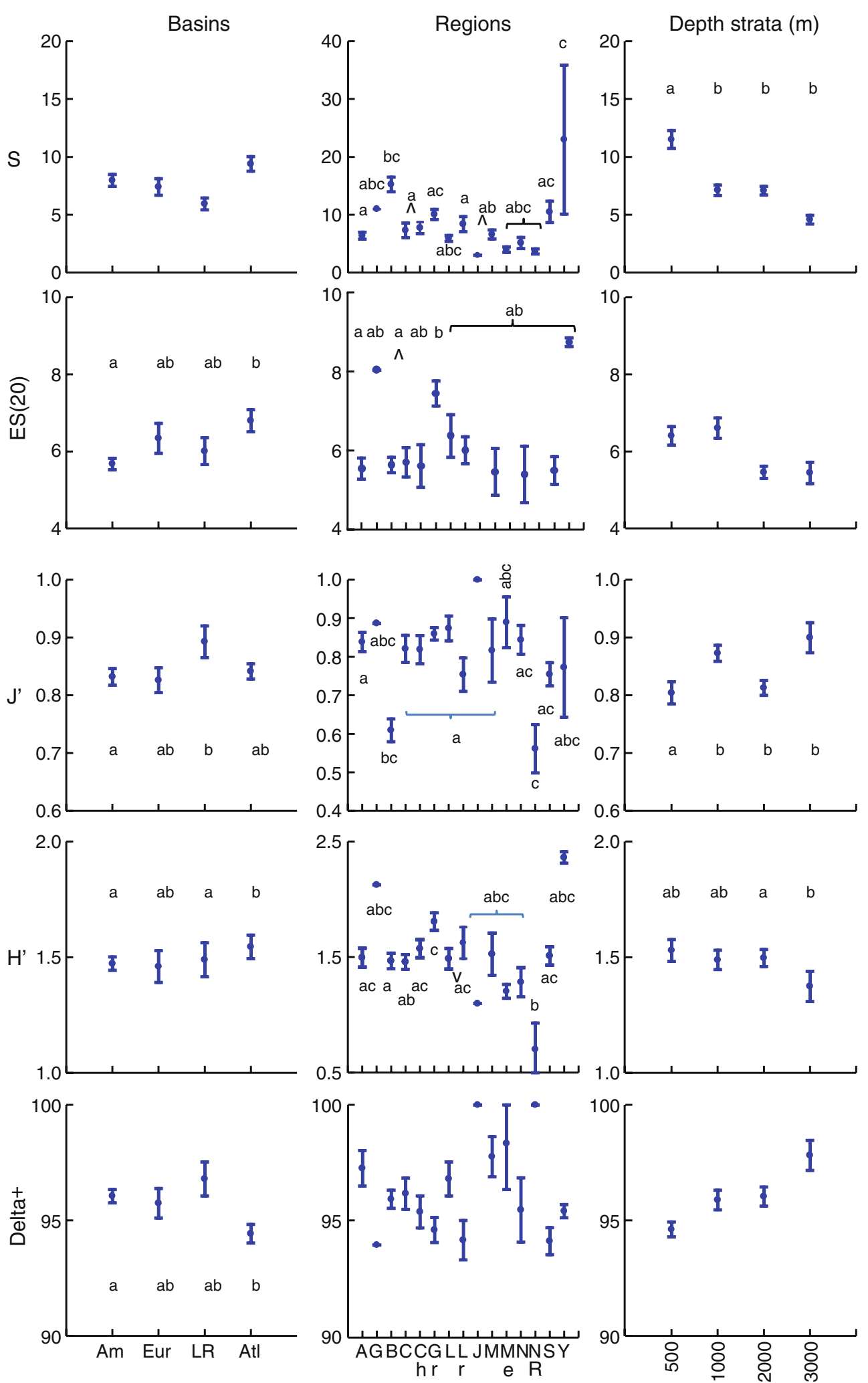

dataset. Some taxa are species poor throughout the world's oceans such as the echiurans with $\sim 160$ species worldwide and 2 of those in the Arctic (Murina, unpublished), and the priapulids with 18 species globally and a high portion of those (4) in the Arctic (Adrianov, unpublished). In contrast, more than 300 species of bryozoans occur on Arctic shelves (Sirenko 2001; Kuklinski, personal communication) and reports on encrusting fauna, including bryozoans, on drop 

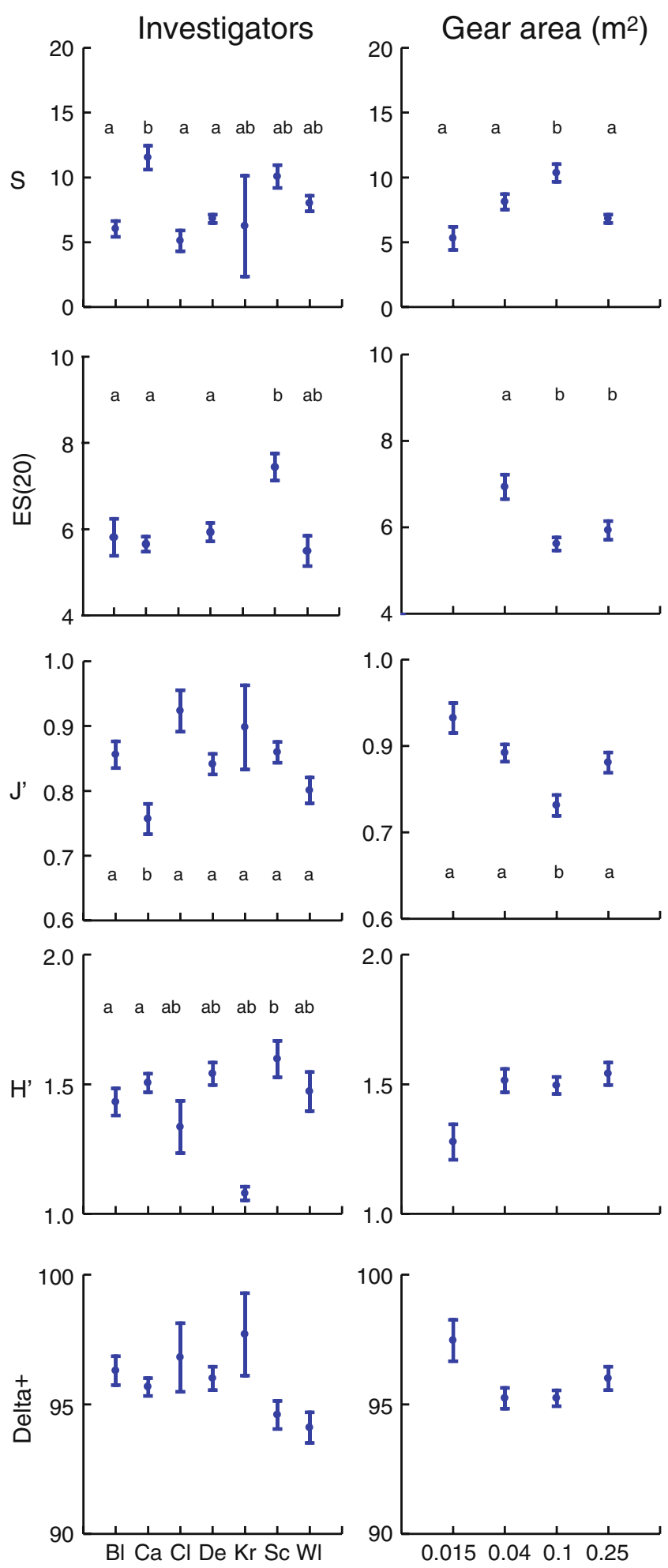

Fig. 8 Means $( \pm$ SE) of diversity indices S, ES(20), J', H', and Delta+ by the confounding factors, investigators and sample size for Arctic deep-sea polychaete communities. Significant differences are indicated by letters. ES(20) was calculated only for samples that contained 20 or more polychaete individuals which reduced the number of gear sampling size. $\mathrm{Bl}$ Bluhm et al., $\mathrm{Ca}$ Carey, $\mathrm{Cl}$ Clough et al., $\mathrm{De}$ Deubel, $\mathrm{Kr}$ Kroencke, $\mathrm{Sc}$ Schnack, $W l$ Włodarska-Kowalczuk et al. Gear sample size categories: $0.0150 .015-0.03 \mathrm{~m}^{2}, 0.040 .04-0.0625 \mathrm{~m}^{2}, 0.10 .1 \mathrm{~m}^{2}, 0.250 .25 \mathrm{~m}^{2}$ stones in the Greenland Sea (Schulz et al. 2010) suggest our list under-represents bryozoans and probably other taxa from this poorly sampled habitat. Within the arthropods, crabs were absent altogether from our dataset as is typical for the high-latitude deep sea. The scarceness of large organisms or organic falls (from phyto-detritus to whales) may also limit the occurrence of large scavengers in these areas.

That about half of all taxa in our dataset were recorded from only one or two locations agrees with the global observation that deep-sea communities have a high proportion of rare species compared to shelf communities (Glover et al. 2002; Rex and Etter 2010). The high level of rareness and endemism (estimated at $50-80 \%$ in the Arctic deep sea - Vinogradova 1997) may be overestimated because of the relatively low sampling intensity. However, other deep-sea areas in the Atlantic, including Porcupine Abyssal Plain $(4,800 \mathrm{~m})$, Rockall Trough permanent station $(2,900 \mathrm{~m})$ and Cap Verde Abyssal Plain (4,800 m), also have high rareness values of over $60 \%$ (G. Paterson, personal communication). The large proportion of rare taxa hinders elucidation of the Arctic basin's relationships to the Atlantic and Pacific deep sea and its species dispersal pathways (Vinogradova 1997). However, the minor separation of the polychaete community structure between the Arctic and North Atlantic basins supports the common view that the modern Arctic deep-sea fauna is closely related to the modern North Atlantic abyssal fauna (e.g., Filatova 1957). Modern Pacific elements are rare, but it is noteworthy that some fauna is secondarily Atlantic and originally Pacific (Golikov and Scarlato 1990). The modern Arctic fauna is thought to be young, of Pleistocene age (Guryanova 1970), and the invasion by benthic organisms from the North Atlantic to higher latitudes is probably still occurring (Guryanova 1938). Repeated invasions of shelf fauna are thought also to be an origin of Arctic deep-sea fauna (e.g., Andriashev $1953)$ and the relatively high number of species shared with the Arctic shelves in our data set $(60 \%$ of the deep-sea fauna) supports this interpretation.

Depth and latitudinal trends

Meiofaunal abundance, macrofaunal abundance and macrofaunal biomass in our study decreased with water depth. This result agrees with a well-documented global trend (Rex et al. 2006; Wei et al. 2011), although some bias was introduced into our analysis by the different mesh sizes used (see Gage et al. 2002 for effects of different mesh sizes on abundance and biomass estimates). The decrease in abundance was greater for macro- than meiofauna, corroborating previous findings of an average decrease in metazoan size with depth (Thiel 1975; Rex and Etter 2010) and the consequent increasing importance of small 
Table 7 Polychaete species richness determined for different deep-sea areas

\begin{tabular}{llllll}
\hline Region & Area $\left(\mathrm{m}^{2}\right)$ & Depth range $(\mathrm{m})$ & Polychaete taxa & Sieve size $(\mu \mathrm{m})$ & Reference \\
\hline Arctic Basin slopes and abyss & $26.4+$ & $500-4,190$ & 194 & $250-1,000$ & This study \\
NW Atlantic slope & 21 & $1,500-2,500$ & 385 & 300 & Grassle and Maciolek 1992 \\
Porcupine Abyssal Plain & 1.25 & 4,800 & 101 & $300-1,000$ & Glover et al. 2001 \\
Northeast Pacific slope and abyss & 6.8 & $550-3,100$ & 382 & 300 & Hilbig and Blake 2006 \\
Central Pacific abyss I & 19.25 & $4,800-5,100$ & 183 & 300 & Glover et al. 2002 \\
Central Pacific abyss II & 2.94 & $4,300-4,800$ & 177 & 300 & Glover et al. 2002 \\
Antarctic, deep Weddell \& Scotia Seas & 1.94 & $1,138-5,194$ & 90 & $300-500$ & Hilbig 2004 \\
\hline
\end{tabular}

organisms (Pfannkuche and Soltwedel 1998; Rex et al. 2006). Abundance and biomass decreases with depth are linked to decreasing food availability as both primary production and lateral input from the shelves drop (Gosselin et al. 1997; Rex et al. 2006). In the Arctic, the increase in depth roughly coincides with an increase in latitude and, hence, increased seasonality in primary production and thickness and persistence of the ice cover exacerbate the depth effect. Nevertheless, the overall range of macrofaunal abundance $\left(0-9,848\right.$ ind $\mathrm{m}^{-2}$, mostly below 4,000 ind $\mathrm{m}^{-2}$ ) in the depth range considered falls within the lower end of values for the temperate and sub-Arctic North Atlantic (50-55,000 ind $\mathrm{m}^{-2}$, but mostly $<4,000$ ind $\mathrm{m}^{-2}$ ). The same holds true for macrofaunal biomass: 0 $2.8 \mathrm{~g} \mathrm{C} \mathrm{m}^{-2}$ but mostly $<1 \mathrm{~g} \mathrm{C} \mathrm{m}^{-2}$ in the Arctic deep sea versus $<0.01-50 \mathrm{~g} \mathrm{C} \mathrm{m}^{-2}$ but mostly $<4 \mathrm{~g} \mathrm{C} \mathrm{m}^{-2}$ in the North Atlantic (Levin and Gooday 2003). Meiofaunal abundances in our data set $\left(72-4,673\right.$ ind $\mathrm{m}^{-2}$ ) also did not generally differ from those at temperate eastern Atlantic locations in the same depth range (20-2,604 ind $\mathrm{m}^{-2}$; Soltwedel 2000; Levin and Gooday 2003). More detailed comparisons and discussion of depth trends and samplingrelated caveats can be found in Soltwedel (2000) and Levin and Gooday (2003).

Like abundance and biomass, the diversity indices $\mathrm{S}, \mathrm{H}$, and Delta + also decreased with latitude and depth, but the decrease was generally quite small. ES(n), an index less dependent on sampling effort than $\mathrm{S}$ and $\mathrm{H}^{\prime}$, did not significantly decrease with latitude. Globally, more pronounced latitudinal clines in diversity than we have recorded were found in different habitats and taxa (e.g., Rex et al. 1993; Boucher and Lambshead 1995; Hillebrand 2004; but see Renaud 2009). Evolutionary and ecological causes that have been proposed for these gradients focus primarily around energy and history (Rohde 1992; Jablonski et al. 2006). Our observations fit with the global trend that diversity tends to be low at low production regimes (the central basins) and higher at intermediate production levels (Arctic shelves and Greenland/Norwegian Basins) (reviewed in Waide et al. 1999; Levin et al. 2001; see also Whitman et al. 2008). The small to moderate decrease of several diversity indices with latitude, however, and the lack thereof for $\operatorname{ES}(20)$, as well as the high variability at similar latitudes, all suggest that variability in total energy input is only of minor importance. Comprehensive exploration of latitudinal diversity gradients and their underlying cause(s) are probably best restricted to consistently collected data that extend beyond the regional scale (Renaud et al. 2009 and unpubl.). Hopefully, our data set will contribute to such future evaluations of latitudinal gradients in the global deep sea.

The continuous decrease in most diversity indices with water depth is in contrast to a considerable body of literature that documents a peak in diversity (mostly species richness) at mid-depths around 1,500-3,000 m (summarized in Rex and Etter 2010). Most data sources underlying this paradigm are from the Atlantic, but a peak in isopod diversity was also found at 3,000 $\mathrm{m}$ in the Antarctic (Brandt et al. 2004). In the Arctic, the known species richness does not appear to follow this pattern: the number of (macro- and megafaunal) species on the shelves is $\sim 2600$ with a predicted total number of 3,900-4,700 (Piepenburg et al. 2010), thus at least double the number we assembled and predicted for the bathyal and abyssal areas. Other authors also describe a lack of a mid-depth peak of diversity in the deep Norwegian Sea (Dauvin et al. 1994; Levin et al. 2001), the central Arctic (Deubel 2000; Renaud et al. 2006) and the Canada Basin (Bluhm et al. 2005). Nonetheless, in the Eurasian Arctic deep sea, a mid-depth peak occurs for macrofauna (Kröncke 1998) and an increase occurs with depth for Foraminifera (Wollenburg and Kuhnt 2000).

Different causes are conceivable for the apparent differences in depth-related patterns between the deep Arctic and Atlantic. Firstly, the Arctic deep sea is heavily undersampled relative to the Arctic shelves, so the true species richness in the bathyal might indeed rival that on the shelves. Secondly, the presence of Pacific species adds to the species richness of the modern Amerasian Arctic shelf fauna (Dunton 1992). In contrast, the Arctic deep-sea fauna is isolated from the deep Pacific, and the rather stenobathic 
Pacific Arctic shelf fauna does not penetrate into bathyal depths (Dahl 1972; Bilyard and Carey 1980; Nesis 1984) like the eurybathic Atlantic Arctic shelf fauna does. Thirdly, it is conceivable that influences thought to enhance diversity such as high sediment heterogeneity, intermediate biotic disturbance, food availability and flow strength levels, and high bottom water oxygen concentrations (reviewed in Levin et al. 2001) may prevail on the Arctic shelves rather than the slopes. Nevertheless, some factors known to decrease diversity, such as low salinity, also prevail on the shelves (Cusson et al. 2007). These latter possibilities require a detailed environmental evaluation that is beyond the scope of this paper. Until mechanisms responsible for generating spatial and depths patterns of diversity are more clearly defined and tested, reasons for the presence or lack of bathyal peaks in Arctic diversity remain elusive.

Basin-wide and regional patterns or sample bias

On the basin-scale, our multivariate analysis of the polychaete fauna supports previous findings that the prominent Lomonosov Ridge does not cause major or abrupt differences in faunal community composition between the Amerasian and Eurasian basins (Koltun 1964; Deubel 2000; Kosobokova et al. 2010). Gaps in the ridge and the circulation regime bringing Atlantic deep water all the way into the Canada Basin apparently support sufficient larval dispersal to connect communities on either side of the ridge. The absence of Pacific influence on the modern Arctic deep-sea fauna (see above) contributes to this relative similarity of the (polychaete) fauna on a panArctic scale when ones discounts the high fraction of poorly-characterized rare species. Of the species originating in the GIN Seas, one might suspect that species with longlived pelagic stages capable of long-distance dispersal might be dominant, a hypothesis we propose should be tested in the future.

While community structure varied little on a basin-scale, several diversity indices did significantly differ, with higher values for ES(20), higher H', and lowest Delta+ in the GIN Seas samples versus the Amerasian Basins, and intermediate levels for the Eurasian Basins (Fig. 7). This pattern has previously been attributed to submergence of slope and shelf species to greater depths in the Greenland and Norwegian Seas than in the central Arctic basins, rather than to higher numbers of true deep-sea species (Vinogradova 1997). In addition, the overlap of boreal and Arctic faunas in the GIN Seas may add to the observed pattern. Lowest S, ES(20) and $H^{\prime}$ in the Amerasian Basin compared to both the Eurasian and GIN Basins may reflect a decreasing extent of species immigration from the Atlantic towards the Amerasian Arctic. Compared to the Atlantic basins south of the GIN Seas, species richness in Arctic and subArctic basins is thought to be lower because of the relative geographic isolation (Dahl 1972; Dauvin et al. 1994). The faunal patterns in the basins suggest that evolutionary history rather than present ecological factors appear to shape the large-scale diversity patterns.

On the regional scale of individual sub-basins, slopes and ridges, some differences were apparent from the multivariate analysis and the comparison of diversity indices of the polychaete fauna. Differences among investigators, however, often coincided with these regional differences, making it difficult to separate study bias from true regional patterns, and illustrating the importance of reliable taxonomic identification to species level (Fig. 6). We illustrate this using the largest regional difference in the polychaete community based on the multivariate analysis: between the Beaufort Sea slope and many other regions including the nearby Chukchi Sea slope. Like the remaining Arctic deep sea, the Beaufort Sea slope is dominated by Atlantic-boreoarctic species and endemics, and characterized by the absence of Pacific-boreoarctic species (Bilyard and Carey 1980). Identifying the taxa that separated the Beaufort Sea slope from the other regions (data not shown) revealed three types of species: (1) species that only occurred on the Beaufort Sea slope, or only in the combined areas of the Beaufort Sea slope and the adjacent Canada Basin, (2) species that occurred in comparatively high abundances on the Beaufort Sea slope and in lower abundances in other regions, and (3) species that we consider 'artificially different' from other regions, because of taxonomic problems.

Taxa groups 1 and 2 may reflect real spatial differences, albeit with limitations. The first group included, for example, Capitella capitata and Sigambra tentaculata. The observation of Sigambra tentaculata in the deep Beaufort Sea, rather than their typical distribution in shallow waters of California, suggests these records belong to the closely related species Sigambra healyae, recently described from the Canada Basin (Gagaev 2008). Capitella capitata, although only found in the Beaufort Sea slope samples in our dataset, may be of limited value as a discriminating species among regions because it consists of at least six sibling species with minor morphological differences (Grassle and Grassle 1976). The third group included, for example, Lumbrineris minuta, while all other investigators identified specimens from this genus as Lumbrineris sp., which can induce artificial differences among regions. Differences in sieve size between studies also added to artificial differences between regions (see Gage et al. 2002 for extensive discussion of sieve size effects on diversity estimates). The above examples, and the rather small separation of regional communities on the family level, suggest that the regions are overall only at 
most modestly different in polychaete community structure. This implies a common species pool consisting of deep-sea and shelf taxa. In contrast to the basin-scale discussed above, environmental and ecological factors may be more likely to explain regional differences within basins than evolutionary ones, since the former vary on smaller scales.

\section{Summary and outlook}

Our study documented a larger number of Arctic benthic deep-sea species than previously recorded $(>1,100$ versus $\sim 700$ a decade ago), and predicts the addition of at least several hundred more with continued sampling effort. Globally-documented decreases of abundance and biomass with depth were confirmed for Arctic meio- and macrofauna. For the polychaete fauna, a decrease of four diversity indices with latitude and depth was significant but minor, and non-significant for latitude for $\operatorname{ES}(20)$. There was no indication of a mid-depth peak in any of the diversity indices employed. We found no separation of the polychaete fauna by the Lomonosov or other ridges, but a high connectivity of the central Arctic to the North Atlantic (GIN Seas) and Arctic shelf faunas, with very limited contemporary connectivity to the Pacific fauna. Regional differences exist but are probably minor, although confounded by sampling inconsistencies.

The distribution of taxon occurrences compiled in this paper and in other publications shows that the largest sampling gaps in Arctic deep-sea invertebrate benthos exist $>3,000 \mathrm{~m}$, on the eastern side of the Canada Basin, and in the megafauna fraction. Not surprisingly, our study also showed that lack of consistency in sampling gear and taxonomic resolution pose problems for pan-Arctic comparisons, possibly masking actual patterns and even producing artificial ones. We recommend that future efforts consider filling the above gaps and use standardized sampling gear with a large surface area and/or sufficient replication to capture true local diversity. A standardized sieve size of $250 \mu \mathrm{m}$ for macrofauna is recommended because of the small size of traditional macrofauna taxa in the deep sea. Small polychaetes and other prominent taxa are neglected if larger sieves sizes were used. The ideal methodology would be a size fractionation of $250 \mu \mathrm{m}$, $500 \mu \mathrm{m}$ and $1 \mathrm{~mm}$ to allow fuller comparison with studies using these alternate sieve sizes.

The data compiled here, while incomplete, will be useful as a baseline for assessing future changes. It is difficult to predict whether abundance and biomass will increase or decrease in the Arctic deep sea in the coming decades. If overall pelagicbenthic coupling were to remain constant, one might predict an increase in abundance and biomass. This prediction is based on the shrinkage in multi-year ice-cover (Stroeve et al. 2007), the predicted increase in pelagic primary production in the central Arctic (Anderson and Kaltin 2006), and the higher deep-sea biomass in Arctic regions lacking perennial sea ice (Włodarska-Kowalczuk et al. 2004). Perhaps more likely, however, is a decrease in carbon flux to the deep-sea floor with a subsequent decrease in abundance and biomass of deep-sea fauna, because of increased retention and recycling of organic matter in the water column (Carroll and Carroll 2003). In terms of diversity, a reasonable prediction of future change is even more difficult, because (1) it is unclear if and how much the carbon flux to the Arctic deep-sea floor will change, and (2) the unimodal distribution of the productivity-diversity relationship found in many studies does not seem to be generally applicable (e.g., Glover et al. 2002). The relationship between productivity and diversity such as studied for the Canadian Arctic shelves (Whitman et al. 2008) remains an open question in the Arctic deep sea. The extreme seasonality associated with high latitude will obviously remain, and will continue to produce different conditions for the high Arctic deep-sea fauna from those in the global deep sea. Ongoing environmental changes in the Arctic set in motion the opportunity for a large-scale "experiment". Repeated longterm sampling in areas of extreme loss of the perennial ice cover should monitor variability and change. Additional long-term deep-sea Arctic observatories like the unique HAUSGARTEN in Fram Strait (Soltwedel 2005) should also be implemented, particularly on the Pacific side on the Chukchi Sea slope.

Acknowledgments We thank everyone who contributed to this study through field work, species identifications, and providing data. We also acknowledge funding for the original field research that was the basis for this synthesis: the United States National Science Foundation, the National Oceanic and Atmospheric Administration, the Russian Academy of Sciences, and the German Federal Ministry of Education and Research. M.B., C.H., M.K., I.S. and T.S. acknowledge the HERMES project funding by the European Commission's Framework Six Programme, under the priority Sustainable Development, Global Change and Ecosystems, Contract No. GOCECT-2005-511234-1 as well as the HERMIONE funding under the European Commission's Framework Seven Programme contract number 226354. The synthesis effort itself that resulted in this paper was supported by the Alfred P. Sloan Foundation, with special thanks to its visionary vice director, J. Ausubel. We gratefully acknowledge the helpful comments by Dr. P. Archambault and two anonymous reviewers that improved an earlier draft of this article. This publication is part of the Census of Marine Life's Arctic Ocean Diversity project synthesis and was originally presented at the Arctic Frontiers Conference in Tromsø, January 2010. The support and initiative of ARCTOS and Arctic Frontiers, in particular Dr. P. Wassmann, are gratefully acknowledged. This is publication awi-n19014

Open Access This article is distributed under the terms of the Creative Commons Attribution Noncommercial License which permits any noncommercial use, distribution, and reproduction in any medium, provided the original author(s) and source are credited. 


\section{References}

Anderson LG, Kaltin S (2006) Carbon fluxes in the Arctic Ocean potential impact by climate change. Polar Res 20:225-232

Andriashev AP (1953) Ancient deep-water and secondary deep-water fishes and their significance in a zoogeographical analysis. In: Notes on special problems in Ichthyology. Izdatelstvo Akademii Nauk SSSR, Moscow, pp 57-64

Billett DSM, Bett BJ, Rice AL, Thurston MH, Galeron J, Sibuet M, Wolff GA (2001) Long-term change in the megabenthos of the porcupine abyssal plain (NE Atlantic). Prog Oceanogr 50:325348

Bilyard GR, Carey AG (1980) Zoogeography of western beaufort sea polychaeta (Annelida). Sarsia 65:19-26

Bluhm BA, MacDonald IR, Debenham C, Iken K (2005) Macro- and megabenthic communities in the high Arctic Canada Basin: initial findings. Polar Biol 28:218-231

Boucher G, Lambshead PJD (1995) Marine nematode ecological biodiversity in samples from temperate, tropical and deep-sea regions. Conserv Biol 9:1-12

Brandt A, Broekeland W, Brix S, Malyutina M (2004) Diversity of Southern Ocean deep-sea Isopoda (Crustacea, Malacostraca) - a comparison with the shelf. Deep Sea Res II 51:1753-1768

Carey AG (1977) Summarization of existing literature and unpublished data on the distribution, abundance and life history of benthic organisms (Beaufort Sea). Outer Continental Shelf Energy Program NOAA/BLM, Final Report

Carroll ML, Carroll J (2003) The Arctic Seas. In: Black B, Shimmield $\mathrm{G}$ (eds) Biogeochemistry of marine systems. Blackwell, Oxford UK, pp 127-156

Clarke KR, Warwick RM (1999) The taxonomic distinctness measure of biodiversity: weighting of step lengths between hierarchical levels. Mar Ecol Prog Ser 184:21-29

Clarke KR, Warwick RM (2001) A further biodiversity index applicable to species lists: variation in taxonomic distinctness. Mar Ecol Prog Ser 216:265-278

Clough LM, Ambrose WG, Cochran JK, Barnes C, Renaud PE, Aller RC (1997) Infaunal density, biomass and bioturbation in the sediments of the Arctic Ocean. Deep Sea Res I 44:16831704

Colwell RK (2000) EstimateS: statistical estimation of species richness and shared species fromsamples (Software and User's Guide), version 6. http://viceroy.eeb.uconn.edu/estimates

Cooper LW, Cota GF, Pomeroy LR, Grebmeier JM, Whitledge T (1999) Modification of NO, PO, and NO/PO during flow across the Bering and Chukchi shelves: implications for use as Arctic water mass tracers. J Geophys Res 104(C4):7827-7836

Cusson M, Archambault P, Aitken A (2007) Biodiversity of Arctic continental shelf benthic assemblages: historical data from the Canadian Arctic Archipelago. Mar Ecol Prog Ser 331:291-304

Dahl E (1972) The Norwegian Sea Deep Water fauna and its derivation. Ambio Special Report, No. 2, The Norwegian Sea Region: Its hydrography, glacial and biological history, pp 19-24

Dauvin JC, Kendall M, Paterson G, Genil F, Jirkov I, Sheader M, De Lange M (1994) An initial assessment of polychaete diversity in the northeastern North Atlantic Ocean. Biodivers Lett 2:171-181

Deubel H (2000) Structures and nutrition requirements of macrozoobenthic communities in the area of the Lomonossov Ridge in the Arctic Ocean (in German). Rep Polar Res 370:1-147

Dunton K (1992) Arctic biogeography: the paradox of the marine benthic fauna and flora. Trends Ecol Evol 7:183-189

Filatova ZA (1957) Zoogeographical zonation of northern seas from the occurrence of bivalve mollusks. Tr Inst Okeanol Akad Nauk SSSR 98:270-276 (in Russian)
Gagaev SY (2008) Sigambra healyae sp. n., a new species of polychaete (Polychaeta: Pilargidae) from the Canada Basin of the Arctic Ocean. Russ J Mar Biol 34:73-75

Gagaev SY (2009) Terebellides irinae sp. n., a new species of Terebellides (Polychaeta: Terebellidae) from the Arctic Basin. Russ J Mar Biol 35:474-478

Gage JD, Hughes DJ, Gonzalex Vecino JL (2002) Sieve size influence on estimating biomass, abundance and diversity in samples of deep-sea macrobenthos. Mar Ecol Prog Ser 225:97-107

Galgani F, Lecornu F (2004) Debris on the sea floor at 'Hausgarten': in the expedition ARKTIS XIX/3 of the research vessel Polarstern in 2003. Ber Polar Meeresforsch 488:260-262

Glover AG, Paterson GLJ, Bett B, Gage J, Sibuet M, Sheader M, Hawkins L (2001) Patterns in polychaete abundance and diversity from the Madeira Abyssal Plain, north-east Atlantic. Deep Sea Res I 48:217-236

Glover AG, Smith CR, Paterson GLJ, Wilson GDF, Hawkins L, Sheader M (2002) Polychaete species diversity in the central Pacific abyss: local and regional patterns, and relationships with productivity. Mar Ecol Prog Ser 240:157-169

Golikov AN, Scarlato OA (1990) History of the development of the Arctic marine ecosystem and their functional peculiarities. In: Kotlyakov VM, Sokolov VE (eds) Arctic Research: Advances and prospects. Proceedings of the Conference of Arctic and Nordic countries on coordination of research in the Arctic, Lenningrad, December 1988. Part 2. Moscow, pp196206

Gosselin M, Levasseur M, Wheeler PA, Horner RA, Booth BC (1997) New measurements of phytoplankton and ice algal production in the Arctic Ocean. Deep Sea Res II 44:1623-1644

Gradinger R (2009) Sea-ice algae: major contributors to primary production and algal biomass in the Chukchi and Beaufort Seas during May/June 2002. Deep Sea Res II 56:1201-1212

Grantz AG, Phillips RL, Mullen MW, Starratt SW, Jones GA, Naidu AS, Finney BP (1996) Character, paleoenvironment, rate of accumulation, and evidence for seismic triggering of Holocene turbidites, Canada Abysal Plain, Arctic Ocean. Mar Geol 133:51-73

Grassle JP, Grassle JF (1976) Sibling species in the marine pollutant indicator Capitella (Polychaeta). Nature 192:567-569

Grassle JF, Maciolek NJ (1992) Deep-sea species richness: regional and local diversity estimates from quantitative bottom samples. Am Nat 139:313-341

Guryanova EF (1938) On the question of the composition and origin of the abyssal fauna of the polar basin. Dokl Akad Nauk SSSR 20:330-336 (in Russian)

Guryanova EF (1970) The particularities of the Arctic fauna and its significance for the interpretation of the history of its formation. In Severnyi Ledovitii okean I ego pobereje $\mathrm{v}$ kainozoe. Izdatelstvo Gidrometeoizdat, Leningrad, pp 126-161 (in Russian)

Hasemann C (2006) Small-scale heterogeneity in the Arctic deep sea: impact of small coldwater-sponges on the diversity of benthic nematode communities. Rep Polar Res 527:294

Hilbig B (2004) Polychaetes of the deep Weddell and Scotia Seas composition and zoogeographical links. Deep Sea Res II $51: 1817-1825$

Hilbig B, Blake JA (2006) Deep-sea polychaete communities in the northeast Pacific Ocean off the Gulf of the Farallones, California. Bull Mar Sci 78:243-269

Hillebrand H (2004) On the generality of the latitudinal diversity gradient. Am Nat 163:192-211

Iken I, Brey T, Wand U, Voigt J, Junghans P (2001) Food web structure of the benthic community at the Porcupine Abyssal Plain (NE Atlantic): a stable isotope analysis. Prog Oceanogr 50:383-405 
Jablonski D, Roy K, Valentine JW (2006) Out of the Tropics: evolutionary dynamics of the latitudinal diversity gradient. Science 314:102-106

Jakobsson M, Grantz A, Kristoffersen Y, Macnab R (2004) Bathymetry and physiography of the Arctic Ocean and its constituent seas. In: Stein R, Macdonald RW (eds) The organic carbon cycle in the Arctic Ocean. Springer, Heidelberg, pp 1-6

Klages M, Boetius A, Christensen JP, Deubel H, Piepenburg D, Schewe I, Soltwedel T (2004) The benthos of Arctic seas and its role for the organic carbon cycle at the seafloor. In: Stein R, Macdonald RW (eds) The organic carbon cycle in the Arctic Ocean. Springer, Heidelberg, pp 139-167

Koltun VM (1964) About the study of the bottom fauna of the Greenland Sea and the central part of the Arctic basin. Tr Arct Antarkt Nauchnoissled Inst 259:13-78, in Russian

Kosobokova KN, Hirche HJ, Hopcroft RR (2010) Patterns of zooplankton diversity through the depths of the Arctic's central basin. Mar Biodiv, this volume

Kröncke I (1994) Macrobenthos composition, abundance and biomass in the Arctic-Ocean along a transect between Svalbard and the Makarov Basin. Polar Biol 14:519-529

Kröncke I (1998) Macrofauna communities in the Amundsen Basin, at the Morris Jesup Rise and at the Yermak Plateau (Eurasian Arctic Ocean). Polar Biol 19:383-392

Lambshead PJD, Tietjen J, Ferrero T, Jensen P (2001) Latitudinal diversity gradients in the deep sea with special reference to North Atlantic nematodes. Mar Ecol Prog Ser 194:159-167

Levin LA, Gooday AJ (2003) The deep Atlantic Ocean. In: Tyler PA (ed) Ecosystems of the World 28, Ecosystems of the deep sea. Elsevier, Amsterdam, pp 111-178

Levin LA, Etter RJ, Rex MA, Gooday AJ, Smith CR, Pineda J, Stuart CT, Hessler RR, Pawson D (2001) Environmental influences on regional deep-sea species diversity. Annu Rev Ecol Syst 32:5193

Lorenz A (2005) Variability of benthic Foraminifera north and south of the Denmark Strait. PhD thesis, Kiel University, Germany

Macdonald RW, Carmack EC, Wallace DWR (1993) Tritium and radiocarbon dating of Canada Basin deep waters. Science 259 (5091):103-104

MacDonald IR, Bluhm BA, Iken K, Gagaev S, Strong S (2010) Benthic macrofaunal and megafaunal assemblages in the Arctic deep-sea Canada Basin. Deep Sea Res II 57:136-152

Magurran AE (2004) Measuring biological diversity. Blackwell, Oxford

Marincovich L Jr, Brouwers EM, Hopkins DM, McKenna MC (1990) Late Mesozoic and Cenozoic paleogeographic and paleoclimatic history of the Arctic Ocean Basin, based upon shallow-water marine faunas and terrestrial vertebrates. In: Gantz A, Johnson L, Sweeny JF (eds) The Arctic Ocean Region. The Geology of North America, vol. L. Geological Society of America, Boulder, Colorado, pp 403-426

Nesis KN (1984) A hypothesis on the origin of western and eastern Arctic distribution of areas of marine bottom animals. Sov J Mar Biol 9:235-243

Olli K, Wassmann P, Reigstad M, Ratkova TN, Arashkevich E, Pasternak A, Matrai P, Knulst J, Tranvik L, Klais R, Jakobsen A (2006) The fate of production in the central Arctic Ocean - topdown regulation by zooplankton expatriates. Prog Oceanogr 72:84-113

Pain SL, Tyler PA, Gage JD (1982) The reproductive biology of the deep-sea asteroids Benthopecten simplex (Perrier), Pectinaster filholi Perrier, and Pontaster tenuispinus Düben \& Koren (Phanerozonia: Benthopectinidae) from the Rockall Trough. J Exp Mar Biol Ecol 65:195-211

Paul AZ, Menzies RJ (1974) Benthic ecology of the high Arctic deep sea. Mar Biol 27:251-262
Pfannkuche O, Soltwedel T (1998) Small benthic size classes along the N.W. European Continental Margin: spatial and temporal variability in activity and biomass. Prog Oceanogr 42:189-207

Piepenburg D (1988) On the composition of the benthic fauna of the western Fram Strait. Rep Polar Res 52:118

Piepenburg D, Archambault P, Ambrose WG Jr, Blanchard A, Bluhm BA, Carroll ML, Conlan K, Cusson M, Feder HM, Grebmeier JM, Jewett SC, Lévesque M, Petryashev VV, Sejr MK, Sirenko B, Włodarska-Kowalczuk M (2010) Towards a pan-Arctic inventory of the species diversity of the macro- and megabenthic fauna of the Arctic shelf seas. Mar Biodiver, this volume

Renaud PE, Ambrose WG, Vanreusel A, Clough LM (2006) Nematode and macrofaunal diversity in central Arctic Ocean benthos. J Exp Mar Biol Ecol 330:297-306

Renaud PE, Webb TJ, Bjørgesæter A, Karakassis I, Kedra M, Kendall MA, Labrune C, Lampadariou N, Somerfield PJ, WlodarskaKowalczuk M, Vanden Berghe E, Claus S, Aleffi IF, Amouroux JM, Bryne KH, Cochrane SJ, Dahle S, Degraer S, Denisenko SG, Deprez T, Dounas C, Fleischer D, Gil J, Grémare A, Janas U, Mackie ASY, Palerud R, Rumohr H, Sardá R, Speybroeck J, Taboada S, Van Hoey G, Weslawski JM, Whomersley P, Zettler ML (2009) Continental-scale patterns in benthic invertebrate diversity: insights from the MacroBen database. Mar Ecol Prog Ser 382:239-252

Rex MA, Etter RJ (2010) Deep-Sea Biodiversity: Pattern and Scale. Harvard University Press, Cambridge, MA

Rex MA, Stuart CT, Hessler RR, Allen JA, Sanders HL, Wilson GDF (1993) Global scale latitudinal patterns of species diversity in the deep-sea benthos. Nature 365:636-639

Rex MA, Etter RJ, Morris JS, Crouse J, McClain CR, Johnson NA, Stuart CT, Deming JW, Thies R, Avery R (2006) Global bathymetric patterns of standing stock and body size in the deep-sea benthos. Mar Ecol Prog Ser 317:1-8

Roberts D, Gebruk A, Levin V, Manship BAD (2000) Feeding and digestive strategies in deposit-feeding holothurians. Oceanogr Mar Biol 38:257-310

Rogacheva A (2007) Revision of the Arctic group of species of the family Elpidiidae (Elasipodida, Holothuroidea). Mar Biol Res 3:367-396

Rohde K (1992) Latitudinal gradients in species diversity: the search for the primary cause. Oikos 65:514-527

Romero-Wetzel MB, Gerlach SA (1991) Abundance, biomass, sizedistribution and bioturbation potential of deep-sea macrozoobenthos on the Vøring Plateau (1200-1500 m, Norwegian Sea). Meeresforschung 33:247-265

Rowe GT (1983) Biomass and production of the deep-sea macrobenthos. In: Rowe GT (ed) The Sea Vol.8, Deep-sea biology. Wiley, New York, pp 453-472

Rudels B, Jones EP, Anderson LG, Kattner G (1994) On the intermediate depth waters of the Arctic Ocean. Geophys Monogr $85: 33-46$

Savin SM, Douglas RC, Stehli FG (1975) Tertiary marine paleotemperatures. Geol Soc Am Bull 86:1499-1510

Schewe I (2001) Small-sized benthic organisms of the Alpha Ridge, central Arctic Ocean. Internat Rev Hydrobiol 86:317-335

Schnack K (1998) Macrofaunal community patterns at the continental margin off East Greenland (in German). Rep Polar Res 294:124

Schulz M, Bergmann M, Kv J, Soltwedel T (2010) Colonisation of hard substrate along a channel system in the deep Greenland Sea. Polar Biol 33:1359-1369

Seiler D (1999) Macrobenthic structure and carbon demand at the continental margin off East Greenland. Rep Polar Res 307:96

Sharma J, Bluhm BA (2010) Diversity of free-living nematodes from macrobenthos in the Arctic deep-sea Canada Basin. Mar Biodivers, Mar Biodiv. doi:10.1007/s12526-010-0060-1 
Sirenko BI (2001) List of species of free-living invertebrates of Eurasian Arctic seas and adjacent deep waters. Explor Fauna Seas 51:1-129

Sirenko BI, Clarke C, Hopcroft RR, Huettmann F, Bluhm BA, Gradinger R, (eds) (2010) The Arctic register of marine species (ARMS) compiled by the Arctic Ocean Diversity (ArcOD) project. Accessed at http://www.marinespecies.org/arms on 26 May 2010

Soltwedel T (2000) Metazoan meiobenthos along continental margins: a review. Prog Oceanogr 46:59-84

Schewe I, Soltwedel T (2003) Benthic response to ice-edge induced particle flux in the Arctic Ocean. Polar Biol 26:610-620

Soltwedel T (2005) Hausgarten, multidisciplinary investigations at a deep-sea, long-term observatory in the Arctic Ocean. Oceanography 18:46-61

Soltwedel T, Mokievsky V, Schewe I, Haseman C (2009a) Yermak Plateau revisited: spatial and temporal patterns of meiofaunal assemblages under permanent ice-coverage. Polar Biol 32:11591176

Soltwedel T, Jaeckisch N, Ritter N, Hasemann C, Bergmann M, Klages M (2009b) Bathymetric patterns of megafaunal assemblages from the arctic deep-sea observatory Hausgarten. Deep Sea Res I 56:1856-1872

Stein R, MacDonald RW (eds) (2004) The organic carbon cycle in the Arctic Ocean. Springer, Berlin

Stein R, Grobe H, Wahsner M (1994) Organic carbon, carbonate, and clay mineral distribution in eastern central Arctic surface sediments. Mar Geol 119:269-285

Stroeve J, Holland MM, Meier W, Scambos T, Serreze M (2007) Arctic sea ice decline: Faster than forecast. Geophys Res Lett 34. doi:10.1029/2007GL02970

Thiel H (1975) The size structure of the deep-sea benthos. Int Rev Gesamten Hydrobiol 60:575-606

Thiel H (2003) Anthropogenic impacts on the deep sea. In: Tyler PA (ed) Ecosystems of the world: the deep sea. Elsevier, Amsterdam
Tyler PA, Pain SL, Gage JD (1982) The reproductive biology of the deep-sea asteroid Bathybiaster vexillifer. J Mar Biol Assoc UK 62:57-69

Vanreusel A, Clough L, Jacobsen K, Ambrose W, Jivaluk J, Ryheul V, Herman R, Vincx M (2000) Meiobenthos of the central Arctic Ocean with special emphasis on the nematode community structure. Deep Sea Res I 47:1855-1879

Vinogradova NG (1997) Zoogeography of the abyssal and hadal zones. Adv Mar Biol 32:326-387

Waide RB, Willig MR, Steiner CF, Mittelbach G, Gough L, Dodson SI, Juday GP, Parmenter R (1999) The relationship between productivity and species richness. Annu Rev Ecol Syst 30:257-300

Wei C-K, Rowe GT, Escobar-Briones E, Boetius A, Soltwedel T, Caley MJ, Soliman Y, Huettmann F, Qu F, Yu Z, Pitcher CR, Haedrich RL, Wicksten MK, Rex MA, Baguley JG, Sharma J, Danovaro R, MacDonald IR, Nunnally CC, Deming JW, Montagna P, Lévesque M, Weslawski JM, WłodarskaKowalczuk M, Ingole BS, Bett BJ, Yool A, Bluhm BA, Iken K, Narayanaswamy BE (2011) Global patterns and predictions of seafloor biomass using random forests. PLoS ONE 5(12):e15323, doi:10.1371/journal.pone.0015323

Whitman JD, Cusson M, Archambault P, Pershing AJ, Mieszkowska N (2008) The relationship between productivity and species diversity in temperate-arctic marine ecosystems. Ecology 89:S66-S80

Wheeler PA, Gosselin M, Sherr E, Thibault D, Kirchman DI, Benner R, Whitledge TE (1996) Active cycling of organic carbon in the central Arctic Ocean. Nature 380:679-699

Włodarska-Kowalczuk M, Kendall MA, Weslawski JM, Klages M, Soltwedel T (2004) Depth gradients of benthic standing stock and diversity on the continental margin at a high latitude ice-free site (off West Spitsbergen, $79^{\circ} \mathrm{N}$ ). Deep Sea Res I 51:1903-1914

Wollenburg JE, Kuhnt A (2000) Living benthic foraminifers from the central Arctic Ocean: faunal composition, standing stock and diversity. Mar Micropaleontol 34:153-185

Yarincik K, O'Dor R (2005) The census of marine life: goals, scope and strategy. Sci Mar 69:201-208 